\title{
Games for groundwater governance: field experiments in Andhra Pradesh, India
}

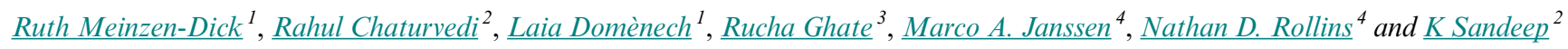

\begin{abstract}
Groundwater is a common-pool resource that is subject to depletion in many places around the world as a result of increased use of irrigation and water-demanding cash crops. Where state capacity to control groundwater use is limited, collective action is important to increase recharge and restrict highly water-consumptive crops. We present results of field experiments in hard rock areas of Andhra Pradesh, India, to examine factors affecting groundwater use. Two nongovernmental organizations (NGOs) ran the games in communities where they were working to improve watershed and water management. Results indicate that, when the links between crop choice and groundwater depletion is made explicit, farmers can act cooperatively to address this problem. Longer NGO involvement in the villages was associated with more cooperative outcomes in the games. Individuals with more education and higher perceived community social capital played more cooperatively, but neither gender nor method of payment had a significantly effect on individual behavior. When participants could repeat the game with communication, similar crop choice patterns were observed. The games provided an entry point for discussion on the understanding of communities of the interconnectedness of groundwater use and crop choice.
\end{abstract}

Key Words: Andhra Pradesh; collective action; experimental games; framed field experiments; groundwater; India

\section{INTRODUCTION}

Groundwater use is a pressing issue in global water management. The key use of groundwater is irrigation, which uses $70 \%$ of global freshwater withdrawals, of which $43 \%$ is from groundwater (Siebert et al. 2010). Groundwater use for irrigation is increasing in absolute and relative terms (Siebert et al. 2010).

India is the world's largest user of groundwater for agriculture (Shah 2009). According to the Fourth Minor Irrigation Census (2006-2007; http://micensus.gov.in/), the numbers of shallow tube wells increased from 8.35 million to 9.12 million, and deep tube wells increased from 0.53 million to 1.44 million, between 2000 2001 and 2006-2007. Today, $>60 \%$ of the irrigation requirements are met by groundwater, clearly indicating the increasing dependence on wells for irrigation. When juxtaposed against the fact that $>85 \%$ of the drinking water requirements in India are met from groundwater (World Bank 2010), there is tremendous pressure on groundwater resources in India. This is reflected in the falling water table levels, indicated in premonsoon decadal trends captured by the Central Ground Water Board (2013): Approximately $50 \%$ of the wells tested showed a water table decline, with $36.77 \%$ of wells showing a decline of $0-2 \mathrm{~m}$ below ground level (bgl), and approximately $13 \%$ of wells showing a decline of $>2 \mathrm{~m} \mathrm{bgl}$, from 2002 to 2012. Declines in water levels in excess of $4 \mathrm{~m} \mathrm{bgl}$ are prominent in the states of Rajasthan, Punjab, Haryana, Delhi, and Andhra Pradesh. In total, 1494 of 4277 blocks (subdistrict administrative units) assessed, or 26\%, fall into the categories of semicritical (using $>70 \%$ of net annual groundwater availability), critical (using $>90 \%$ ), or overexploited (using $>100 \%$ of recharge); all of these categories have significant long-term decline in pre- or postmonsoonal water levels.

Groundwater is a common-pool resource: exploitation by one user reduces groundwater availability for the rest of the users, but it is very difficult to exclude users or limit their extraction, provided they have the land and financing necessary for a well and pump (Ostrom et al. 1999). Detection of free-riding behavior is also typically a challenge because the resource is not directly observable, and, unlike surface irrigation, users are not drawing from a visible common channel but individually from a concealed aquifer. Like users of many other common-pool resources, farmers using groundwater in many places around the world face a dilemma: they have to choose between short-term individual gains from resource extraction and long-term sustainability of the resource, especially in hard rock aquifers where recharge is limited and highly water-consumptive crops are more profitable than crops with low water consumption (Garduño et al. 2009).

Many analysts emphasize the role of the state in controlling groundwater exploitation (e.g., Ross and Martinez-Santos 2010 for Australia and Spain). However, state control requires a high degree of state capacity to monitor groundwater levels and use by many dispersed users. Bekkar et al. (2009) argue that state action is necessary but insufficient for effective groundwater management. Even where there is state capacity, additional community efforts are often needed for effective groundwater management (Mitchell et al. 2011).

In India, the government has had limited capacity to regulate groundwater use (Shah et al. 2012). The major state regulatory measure focuses on blocks that have been declared to be using too high a proportion of recharge by restricting the issuance of electricity connections for pumps within a certain distance of existing wells or by regulating the supply of electricity to wells. However, farmers with electricity connections often receive flat rate or highly subsidized rural electricity, which creates little incentive to conserve water. The political economy of agriculture in India has limited the implementation of these or other state

\footnotetext{
${ }^{1}$ International Food Policy Research Institute, ${ }^{2}$ Foundation for Ecological Security, ${ }^{3}$ International Center for Integrated Mountain Development,

${ }^{4}$ Arizona State University
} 
measures to control groundwater (Mukerji and Shah 2005, Mukherji 2006, Faysse and Petit 2012), and those who can purchase diesel pumps can often get around the regulations.

Collective institutions for self-regulation of resource use have evolved to address such common-pool resource dilemmas in many contexts, including surface irrigation, forests, and rangelands. However, groundwater presents particular challenges to the evolution of such commons management owing to the lack of clear boundaries or visibility of the resource stocks and flows and the difficulty of regulating the installation and use of wells on individual land holdings. Ostrom's (1965) dissertation examined such institutions for groundwater governance in California, and work by Blomquist (1992) and others has examined factors that contribute to such arrangements.

What can be done when such self-governance does not emerge? As noted by the World Bank (2010:xvii), "While the 'what-to-do' elements of successful community action on groundwater management are broadly known - actionable resource information, social mobilization, and incentives to facilitate change - there is a notable lack of proven models for community based groundwater management." One response has been to work through nongovernmental organizations (NGOs) to raise awareness of the problems of groundwater overextraction and ways of addressing them (Garduño et al. 2009). Methods can include increasing groundwater recharge through management in the upper catchment, but usually also need to include some form of demand management to restrict withdrawals, usually through forms of community groundwater budgeting or limitations on types of crops grown or technologies for water extraction and application (notably drip irrigation). Crop choice is particularly useful because it has an important effect on groundwater use and is relatively easy to understand and monitor, an example of the type of simple rules with low transaction costs that van Steenbergen (2006) identifies as important in providing the basis for community action. Ultimately, however, the success of such measures depends on farmers' decisions. Bekkar et al. (2009), Kuper et al. (2009), and Faysse et al. (2014) found that interventions to help farmers understand the nature of groundwater resources and how their actions could affect the resource conditions could provide the basis for community responses. These interventions are examples of the kinds of social learning that that bring stakeholders together to develop the capacity and trust needed for collaboration, which Pahl-Wostl et al. (2007, 2008) argue are increasingly important for water management.

Several studies have examined the determinants of collective action and human behavior using different approaches, including qualitative and quantitative data collection and analysis, common-pool resource experiments, and action research (Baland and Platteau 1996, Meinzen-Dick et al. 2002, Poteete et al. 2010, Janssen and Anderies 2011). A growing number of researchers use framed field experiments (also referred to as experimental games) with farmers in rural communities to collect information on how people, facing real-life resource challenges such as scarce water supplies, behave and work together to solve collective problems. Such methods are increasingly used to measure collective action and test theories about behavior regarding common-pool resources, including irrigation (Cardenas 2000,
Anderies et al. 2011, Janssen and Anderies 2011, Janssen et al. 2012, Cardenas et al. 2013).

Here, we examine the main factors that affect the behavior and attitudes of groundwater users regarding the governance and management of this common-pool resource in Andhra Pradesh, India. We used a framed field experiment to look at how people make decisions related to what crops to plant and how much groundwater to use. Most of the earlier studies on groundwater experiments were performed with student participants (but see Salcedo Du Bois 2014). Our study is performed with farmers who experience groundwater problems in hard rock aquifers in Andhra Pradesh, India. We aim to understand the social and biophysical contextual variables that can explain the decisions of the participants on simulated crop choice, to understand the factors that affect groundwater use in practice. A better understanding of the factors that influence people's behavior about groundwater use can be very valuable for the design of future programs aiming at improving groundwater governance in India.

We next provide background information on the field study context in Andhra Pradesh. This is followed by a brief review of the literature on framed field experiments on common-pool resource management in irrigation. We then describe the design of the overall study and the experimental game. Finally, we present and analyze the results at the individual and group level, and conclude with implications of these findings for groundwater governance.

\section{GROUNDWATER SITUATION IN ANDHRA PRADESH}

The state of Andhra Pradesh in India is highly dependent on groundwater, which is used to irrigate an area of 3.17 million ha, more than half of the total area under irrigation (6.28 million ha), and to meet approximately $80 \%$ of the drinking water needs of the growing population (Directorate of Groundwater, http:// www.aponline.gov.in/apportal/departments/departments.aspx? $\underline{\mathrm{dep}}=20$ \&org=148\&category=about\#file4). Most of this groundwater is from hard rock aquifers, which have patchy areas of groundwater and low storage (World Bank 2010). Since the mid-1980s, groundwater use has increased dramatically, leading to falling groundwater tables. Since the 1980s, the number of wells has increased from 800,000 to 2.5 million, and the land under groundwater irrigation has almost tripled (Directorate of Groundwater, http://www.aponline.gov.in/apportal/departments/ departments.aspx?dep=20\&org=148\&category=about\#file4). The state is divided into 1227 groundwater blocks, of which 300 were at critical or overexploited levels in 2008, and 208 were at semicritical levels (World Bank 2010). Kumar et al. (2011) depict a more pessimistic situation and argue that groundwater overexploitation has been underestimated because of an underestimation of the outflows of the systems. They argue that groundwater irrigation exceeded sustainable withdrawals in 2000 2001.

Reversing this situation is not an easy task. Even though groundwater is a common-pool resource, in most of Andhra Pradesh, groundwater is not managed under a common property regime, which poses serious risks for the future of the resource. Owing to the invisible character of the resource and the difficulties to monitor private pumping, enforcing specific legislation to regulate groundwater use is difficult and expensive (Kemper 2007). Individuals construct and operate wells, and although there 
are regulations on the development of wells within a certain distance of an existing well, unless the well owner applies for an electricity connection, there is little that the state does to enforce well development, much less their operation. Lack of information about the underlying resource dynamics, especially in hard rock aquifers, makes it difficult for communities to act. Moreover, groundwater can take a long time to renew, further masking the relationship between use, recharge, and water availability. Private financing for wells means that wealthier farmers have an advantage in obtaining groundwater because they are better able to afford pumps and well deepening.

Several programs and initiatives have been developed in India and Andhra Pradesh to address the problem of groundwater overexploitation. In 2002, the government of India developed the National Groundwater Recharge Master Plan to encourage the recuperation of groundwater levels through artificial groundwater recharge. The plan estimates that a total of 36 billion $\mathrm{m}^{3}$ can be recharged by using specific recharge structures and rooftop rainwater harvesting in urban areas (World Bank 2010). However, the World Bank (2010) argues that the Master Plan may fail to reach the areas where groundwater overexploitation is more severe because of the criteria used to identify the most suitable recharge areas, which include availability of surplus water and availability of storage space in aquifers. Two major strategies for addressing groundwater depletion are: (1) increasing recharge through watershed management, and (2) reducing extractions through community-based groundwater management, which may include restrictions on new wells, sharing water from existing wells, groundwater budgeting, and limitations on water-intensive crops (for a review of three major approaches used in Andhra Pradesh, see Reddy et al. 2014; see also Garduño et al. 2009). Crop choice, in particular, is a visible indicator of groundwater use, but the links between crops and groundwater use is not always understood in communities.

The Foundation for Ecological Security (FES) and Jana Jagriti (JJ; meaning "awakening people") are two NGOs that have been working with communities in Andhra Pradesh to strengthen governance of common-pool resources, including water management. JJ has been working in 26 habitations, across three mandals (administrative divisions) of Chittoor and Anantapur, for over two decades, on issues related to rural livelihoods and natural resource governance. Its work includes activities such as promoting sustainable agriculture, developing watersheds, crafting institutional arrangements to strengthen land and water governance, and generating public awareness. The organization has a team of dedicated field-level functionaries who are constantly interacting with the communities in villages where they work to identify and address the issues that people are facing with respect to their livelihoods. Most of the funding for this work comes from various government sources such as the National Bank for Agriculture and Rural Development (NABARD; the apex rural refinance institution in India), watershed development programs, and other government watershed development initiatives. FES works in $>8000$ villages in eight states in India to promote the conservation and sustainable management of natural resources, forests, and water in particular, through local selfgovernance institutions. FES has diversified funding from Indian and international funding sources; funding for the work in Ananthapur has come from NABARD, Hindustan Unilever Foundation, and Tata Trusts. Both NGOs have provided the tools and expertise for villagers to measure their groundwater levels and worked with the villagers to see the relations between water budgets, crop choice, and groundwater levels.

FES and JJ work on watershed management in Ananthapur and Chittoor districts, which are classified as arid to semiarid, with an average of 500 to $700 \mathrm{~mm} / \mathrm{yr}$ of rainfall. Ananthapur is one of the most water-hungry districts in the country, with $>100,000$ minor irrigation units (Fourth Minor Irrigation Census; $\underline{\text { http:// }}$ micensus.gov.in/). In Ananthapur, the proportion of area irrigated by tube wells rose from $44 \%$ in $1998-2001$ to $76 \%$ in 2010-2012; during the same period, the proportion of area irrigated by dug and open wells declined from $27 \%$ to just $4 \%$, and that by tanks declined from $22 \%$ to approximately $15 \%$ (based on three-year averages derived from figures from the Department of Irrigation and Canal Area Development of the Government of Andhra Pradesh for 1998-1999 to 2011-2012).

Given the absence of perennial rivers, Ananthapur has always relied on the indigenous rainwater harvesting and management systems such as feeder channels, cascading chains of tanks, and networking water bodies (Rukmini and Manjula 2009). These water bodies were an integral part of the economic and cultural fabric of the rural communities of Ananthapur. A survey conducted in 2004 by the District Collector of Ananthapur identified $>5800$ water bodies, of which 1373 were large tanks with a command area of $>0.4 \mathrm{~km}^{2}$, and 2094 were small tanks. The survey found that one-quarter of the identified water bodies were dysfunctional; the meteoric rise in the number of tube wells eroded incentives to manage community-based irrigation systems that had been the bulwark of agriculture and, indeed, much of rural economy in Ananthapur. Given that many households in the district cannot afford tube wells, along with the simultaneous enfeebling of traditional irrigation sources such as tanks, a large number of farmers cannot practice agriculture with reasonable assurance. These farmers are finding themselves in a position where they are forced to cut down on cultivation or find themselves in unmanageable debt traps.

Ananthapur predominantly has crystalline rock formations, which means that there are large fluctuations in groundwater levels. Although water levels are healthy during the rainy season and after a good monsoon, they rapidly drop with the advance of the dry season. In years when rainfall is subpar, which is often, considering that Ananthapur is one of the most drought-prone districts in India, the decline in groundwater levels is precarious. This situation needs to be examined in light of the changing agricultural patterns in the district. Today, water-intensive crops such as tomatoes, sunflower, mulberry, and paddy dominate the agricultural landscape of the district, gradually elbowing out crops such as millets and pulses. This trend, together with that of oft-recurring droughts, has led to depletion of the aquifers. Analysis of time-series data indicates that $55 \%$ of wells in Ananthapur show falling water levels, ranging between 0.15 and $0.65 \mathrm{~m} / \mathrm{yr}$. Premonsoon trends indicate that $87 \%$ of wells in Ananthapur witnessed a fall in water levels over the 2000-2012 period (Central Ground Water Board 2012). Of the 65 mandals in the district, $>40$ are in the critical, semicritical, and overexploited categories (Central Ground Water Board 2012).

Our study was conducted in the NP Kunta and Tanakal mandals of Ananthapur. Although both of these mandals fall in the safe category, groundwater depletion is a clear and present danger. 
Many of the gram panchayats (lowest level government units, containing several habitations) in these mandals experience acute water shortage during summers, which becomes exacerbated during droughts. This brings significant losses to farmers, but even nonfarmers are affected by falling water tables depleting domestic water supplies. Women are particularly affected because they are generally responsible for household domestic water supplies, which also depend on groundwater. In many villages where the experimental games were organized, the groundwater has high fluoride content, posing significant health hazards. The paucity of potable water is forcing many people to buy water cans on a regular basis, which adds to the financial burden of rural households. Finally, in some cases, the shortage of water for drinking and irrigation is forcing households to migrate. These facts point to the urgency of effecting sound groundwater governance mechanisms to strengthen the backbone of the rural economy of Ananthapur.

\section{EXPERIMENTAL GAMES TO STUDY IRRIGATION}

Framed field experiments are frequently used to obtain a better understanding about how decisions on the use of natural resources are being made and which factors affect cooperation decisions (Cardenas and Carpenter 2008, Vollan 2008, Anderies et al. 2011, Prediger et al. 2011). Such experimental games allow researchers to isolate particular aspects of the institutional arrangements (such as the ability to communicate), as well as study the effect of user characteristics on decision-making. They are designed to test hypotheses of specific research questions, such as the effect of cheap talk or costly sanctioning (Ostrom et al. 1994, Fehr and Gächter 2000), or the sensitivity of findings for different cultures (Cardenas 2000, Cardenas et al. 2000, Herrmann et al. 2008, Henrich et al. 2010). Basic insights on factors affecting cooperation are robust for different types of cultures, although contextual factors affect the level of cooperation in the various social dilemma experiments.

Framed field experiments on common-pool resources typically assume the same decision problem in each round, where changes in the outcomes over the rounds is caused by changes in the decisions of the participants (Ostrom et al. 1994). In a typical experiment, the payoff structure is explained in detail, and participants are tested on their understanding of the instructions before the actual game is started. All decisions are made in private, and the participants receive individual monetary payments based on the decisions they made; the payments are provided in private after the experiment.

Such games only allow us to observe decisions made during the experiments, and therefore, one may question the external validity of the findings of the experiments. However, framed field experiments with actual resource users indicate that decisions made in the experiments explain independent observations of actual resource use (Rustagi et al. 2010, Anderies et al. 2011).

One of the recent developments in framed field experimental studies for common-pool resources is the more explicit inclusion of ecological dynamics (Janssen et al. 2010, 2012, Cardenas et al. 2013). By including dynamics such as the depletion of the resource, experiments show that participants are more sensitive to myopic behavior of overharvesting, prioritizing short-run over long-run gains (Herr et al. 1997, Moxnes 1998a,b). In the experiment we performed, participants could deplete the groundwater resource over time, where time was represented as the rounds of the experiment.

There is a modest literature of experimental studies on commonpool resources that explicitly focus on groundwater. Gardner et al. (1997) show that a quota system leads to the best outcomes for groups sharing groundwater compared to restricting entry to a smaller number of participants. Suter et al. (2012) show that a spatial representation of a groundwater game leads to less myopic behavior compared to a nonspatial representation. Salcedo Du Bois (2014) compared groundwater experiments with student participants and Mexican farmers and found less myopic behavior with the student participants. The experimental design we used is within the tradition of Cardenas et al. (2013), in which a resource is replenished a small amount each round independently of how heavily the resource is used, and participants can overharvest the resource if they extract more resource units than are replenished.

Groundwater resources show some particular challenges that hinder the development of collaborative outcomes. Individual farmers can easily gain access to groundwater resources if they own or lease land and can invest in a well. However, developing self-governance norms for groundwater systems is usually more challenging because irrigators may have limited information about the boundaries, structure, and capacity of the commonpool resource (Schlager 2007). Because the participants are farmers with small land holdings and few alternatives for income generation, choosing whether or not to use irrigation can mean the difference between subsistence-level living and slightly better living standards. Owing to the invisible character of groundwater resources, appropriation and provision problems are initially less obvious to groundwater users. The game we designed makes explicit the effect of individuals' crop choice on overall groundwater levels and then examines the factors that affect farmers' choice of water-consumptive (but profitable) or less water-consumptive (but less profitable) crops. The subsequent debriefing sessions within the community link the game to actual experiences of groundwater use and depletion and provide an entry for NGOs to discuss what the community might do to manage their groundwater more sustainably. However, our focus here is on the factors affecting crop choice.

\section{METHODS}

\section{Game structure}

We used a field experiment framed as a groundwater governance exercise to simulate the effects of crop choice on groundwater levels (see Appendix 1 for the detailed experiment protocol). In each habitation (a named, distinct cluster of houses that constitutes the local community), two groups of participants were recruited: five men and five women. During the session, other community members were excluded from the room where the experiment was conducted to minimize distractions or outsiders' influence on the participants. Each group played two sequential games of 10 rounds each (although the players were not told how many rounds there would be). In the first game, no communication between the participants was allowed. After the first game was completed, the group was instructed to discuss the game with each other for $3 \mathrm{~min}$. A field team member acted as secretary, recording the topics discussed during the communication periods. Following the discussion, a second game 
was played, this time with short communication periods of up to 1 min following each round.

At the beginning of each experiment, the group shared a single shared groundwater resource of 50 units. During each round, the participants were asked to choose one of two crops for planting: Crop A, which used one unit of groundwater and provided two units of income; or Crop B, which used three units of groundwater and provided five units of income. Players were instructed that each round simulated the rabi, or dry season, which depends primarily on groundwater. The participants recorded their crop choice in private on a handheld paper form. Their decisions were recorded by a field team member, and the resulting payoff for each participant was written onto their decision form. The total number of water units consumed by the group was recorded publicly on the presentation board to show how many units of groundwater remained (Fig. 1). Designed to be used for the instruction process at the beginning of the experiment session and for conducting the game itself, the presentation board was printed with an illustration of different types of crops, a bore well, a column to show the water table, an illustration of the water consumption and payoffs for each crop, and a demonstration chart of the water table at the end of each round if all players were to choose Crop A or Crop B. At the beginning of each round following round 1 , aquifer recharge was simulated by adding 5 units of water to the total groundwater resource. The group played the game for 10 rounds or until, at the end of a round, the groundwater resource had $<10$ units of water remaining. This condition ensured that at least 15 units of water would be available after replenishment and all participants could choose Crop B without reaching negative amounts of groundwater.

Fig. 1. Visual aid used in explaining the groundwater game.

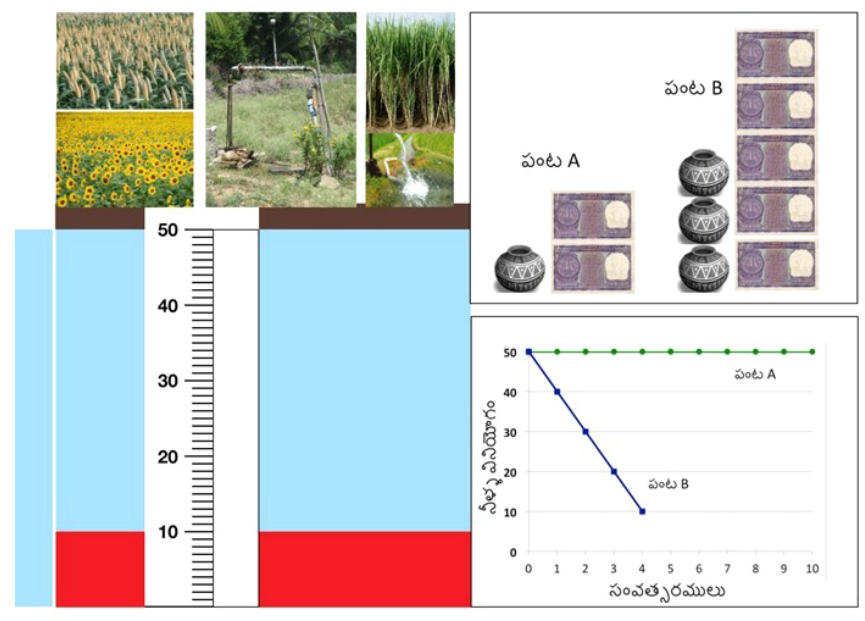

The water demand-payoff structure of the game was set up so that if all participants chose to plant Crop A every round, the game could continue indefinitely. If all chose Crop B, the groundwater resource would be depleted and the game ended after four rounds, which is the Nash equilibrium in which each actor is assumed to be rational, to act in their own self-interest, and to assume the others do likewise. The group earnings under the Nash equilibrium would be 100 units of income. There are many game variations consisting of choice combinations of Crop B (22 times) and Crop A (28 times) that lead to the social optimum, where the group earns 166 units of income. If properly coordinated, the groundwater resource can last for the full 10 rounds, only becoming exhausted at the end of the 10th round. The participants were not told that there would be 10 rounds in the game, although after playing the first game, it would have been generally clear for the second game.

Following the sessions with both men's and women's groups, the field team conducted a community-wide debriefing meeting to discuss the groundwater exercise and aggregate the results from the games. The debriefing was a form of participatory exercise to encourage discussion of the issues around groundwater depletion and what farmers could do about it. In this, the debriefing was similar to the participatory workshops to discuss groundwater issues in France, Portugal, and Morocco, as described by Faysse et al. (2014), but without including government agencies, and using the games as a starting point for discussion. Our community debriefing was usually held in the afternoon or evening after the games, but in some cases, it had to be held on a following day. The debriefing was a guided conversation for game participants to relate their experiences from the game to the groundwater situation in their area and to discuss with other community members possible courses of action. As in the experiment sessions, a field team member acted as secretary, writing notes on the discussion and comments raised during the meeting. We also collected a brief survey from each participant after they had participated in the game. The survey covered background information about the individual, their household, as well as their attitudes toward environmental issues, to be used to assess factors that might explain their choices in the game.

\section{Payment method}

Most field experiments pay individuals based on their "earnings" during the game. In line with the principles of experimental economics, a real, substantial incentive is provided for the decisions to be made. The earnings vary depending on how participants play the game, recreating the kind of commons dilemma faced in practice: individuals will get more monetary earnings if they choose the more water-intensive crop, but if the whole group does that, the water is depleted faster and they will earn less than if they chose the more sustainable crop. So some individuals will be paid more than others, and this is expected to affect how they play (Smith and Walker 1993).

In this project, the participating NGOs are interested in using the groundwater games in their community organizing activities after the project is completed. Preliminary outcomes have been positive. However, individual payments are less feasible in their project management approach. It is becoming standard practice for NGOs to make a contribution to a community fund when the community members participate in studies, and it is important to determine what effect, if any, using a different payment scheme would have on the games and their utility for the NGOs. We therefore organized the experiments with two treatments controlling for payment method to test whether, in this field environment, the payment scheme affected behavior in the games.

Participants in the individual-payments treatment received Rs 5 for each unit of income earned in both games. Their earnings varied depending on how they played the game, and total earnings could range between Rs 200 and 500 per participant in the 
individual-payments treatment. For comparative purposes, the daily wage for National Rural Employment Guarantee Act (NREGA) projects is Rs 115. All households are entitled to up to 100 days of employment at NREGA sites, but this is often hard physical labor. In the flat-fee treatment, individual participants were not paid, but the local watershed committee was given a donation of Rs 2000. Only one approach, either individual or flatfee payments, was used in each community to prevent crosscontamination. People who participated but did not receive individual payments did not see the others being paid individual earnings. We also included control communities, i.e., habitations that were covered by the same watershed management programs from the government and the NGOs but did not participate in the games. This was to allow us to subsequently test whether the games had an effect on collective action. Because the control communities did not play the games, they are not included here.

\section{Sampling}

To allocate habitations to the treatment and control groups, we drew a stratified systematic sample with a random start. The process involved listing all the habitations according to watershed (four where FES is working, and three where $\mathbf{J} \mathbf{J}$ operates), and then within each watershed, by the number of houses. We verified that each habitation uses groundwater for irrigation from bore wells or open wells. We then randomly drew a number between one and three for the start. That habitation on the list received treatment A (individual payments), then we proceeded down the list with treatment B (flat fee to watershed committee), C(control), and cycling back to $\mathrm{A}$ to continue the assignments.

This sampling method was used because with relatively small sample sizes, it is an efficient way to ensure that the sample is distributed across key variables that are likely to affect outcomes. In this case, we stratified on watershed and size of community. Watersheds might affect behavior because of different rainfall patterns or other factors such as different effectiveness of the watershed development programs, NGOs, or field staff assigned to the watershed. Number of houses is a good proxy for number of households or decision makers; the size of the community is often hypothesized to affect collective action (Olson 1965, Ostrom 1990, Agrawal 2001).

The resulting sample had nine habitations in treatment $\mathrm{A}$ and eight habitations in treatment B (see Table 2.1 in Appendix 1). To select the participants within each site, the study team contacted the watershed community to ask them to identify five men and five women from households that use groundwater for irrigation to participate in an activity that looks at how people make decisions on what crops to plant. Although men are reported (by men and women) to be the primary decision makers on what crops to grow and how to irrigate, we wanted to see if women would have different preferences or ways of dealing with trade-offs between short-term income and long-term water tables. Participants were told that the activity would take approximately $2.5 \mathrm{~h}$, they would need to come together in a group for that whole time, and they would have to answer a short survey on a later day. All participants did not need to own wells; if they used water from a neighbor, that was also acceptable. The men and women could not be from the same household, and the committee was asked to select participants that came from different farm-holding sizes. The committee was also told whether individuals would be paid based on the outcome of the activity or there would be a joint payment to the watershed committee (but was not told that other payment options were being used in other habitations), and that a debriefing would be held for the whole community after the activity.

\section{Models}

The data used in the analysis of water use in the groundwater game are derived from 34 experiment sessions performed in Andhra Pradesh, India between February and May 2013. The data set consists of 170 people in 34 groups from 17 villages. Each group played two games, once without and once with communication. Two groups were recruited in each village: a men's group and a women's group. Each group consisted of five participants, and each participant recorded their crop choice for 10 rounds or until the water table dropped below 10 units, whichever came first, resulting in a total of 3400 observations.

In both Models 1 and 2, the dependent variable is crop choice (and consequently water use). We analyzed both individual- and group-aggregate decisions to verify the robustness of our results. The individual-level analysis used logistic regression (logit) to estimate the probability of choosing the more water-consumptive crop (B). The group-level analysis used ordinary least squares regression (OLS) of total water use, with robust standard errors.

The first set of independent variables in both models relates to the game structure: the groundwater level at the start of each round, the payment type (individual or flat fee), and whether communication was allowed. The groundwater level was included because when water is more abundant, we would expect less effort to save water (see Bardhan 1993). Payment type was included to test whether individual payment based on winnings in the game (the standard in experimental games) actually affects behavior (Gneezy et al. 2011). Communication was included because it is hypothesized to increase cooperation (Cardenas and Carpenter 2008). The next variable is the number of years that the NGO has been working in the habitation, to test whether exposure to an NGO promoting groundwater management increases cooperative outcomes, consistent with Baland and Platteau's (1996) observation that a history of successful cooperation increases future cooperation. We also included basic demographic variables, including gender, age, education, caste, household size, and an interaction effect for gender and education (because women have lower education, overall, than do men). We hypothesized that women would be more water-saving because they are more severely affected by groundwater depletion, and that education would make people more aware of the interactions between irrigation and water levels and, hence, more waterconserving. Including caste tests whether higher-status people are more or less cooperative (Lecoutere et al. 2015).

Because social capital is hypothesized to increase collective action (Agrawal 2001), we developed a social capital indicator from the following series of questions on the individual survey:

1. If a neighbor in this village lends some money to another neighbor, it is very likely that the lender gets the money back (values 1 to 5).

2. Suppose that 10 of your neighbors are invited to help in community activities. How many would show up? (values 0 to 10$)$. 
Table 1. Definition and summary of the independent variables used in the analysis. Values in square brackets give ranges of continuous variables; values in curvy brackets are possible values of categorical variables.

\begin{tabular}{|c|c|c|c|}
\hline Variable & Definition & Value range & Mean \\
\hline Available water & $\begin{array}{l}\text { Quantity of groundwater available at beginning of } \\
\text { round, after recharge }\end{array}$ & {$[0,50]$} & 33.287 units \\
\hline Flat fee & Flat-fee treatment used & $\{0,1\}$ & 0.471 games \\
\hline Communication & Communication allowed & $\{0,1\}$ & 1.412 games \\
\hline Round & Round number in game & {$[1,10]$} & \\
\hline Years in program & $\begin{array}{l}\text { Number of years village has participated in } \\
\text { nongovernmental organization program }\end{array}$ & {$[6,20]$} & $11.6 \mathrm{yr}$ \\
\hline Female & Female participant & $\{0,1\}$ & 0.5 \\
\hline Age & Participant's age & {$[20,86]$} & $38.5 \mathrm{yr}$ \\
\hline Caste & Participants' caste category & $\begin{array}{c}\{4=\text { scheduled tribe, } 3=\text { scheduled } \\
\text { caste, } 2=\text { other backward castes, } 1= \\
\text { other castes }\}\end{array}$ & 1.78 \\
\hline Education & Highest education level achieved & $\begin{array}{c}\{0=\text { none, } 1=\text { adult literacy class, } 2= \\
\text { primary school, } 3=\text { secondary school, } \\
4=\text { intermediate school, } 5=\text { technical } \\
\text { school, } 6=\text { university }\}\end{array}$ & 2.02 \\
\hline Female $\times$ Education & Interaction effect for women and education level & {$[0,6]$} & 0.82 \\
\hline Household size & $\begin{array}{l}\text { Total number of people living in household (adults and } \\
\text { children) }\end{array}$ & {$[1, N]$} & 4.8 people \\
\hline Social capital & $\begin{array}{l}\text { Social capital metric based on related questions from the } \\
\text { individual survey }\end{array}$ & {$[0,1]$} & 0.969 \\
\hline Area owned & Total area of land owned (ha) & {$[0, N]$} & 2.105 \\
\hline Area tank-irrigated & Area of land irrigated by tank water (ha) & {$[0, N]$} & 0.131 \\
\hline Area groundwater-irrigated & Area of land irrigated by groundwater (ha) & {$[0, N]$} & 0.630 \\
\hline
\end{tabular}

3. If a mother in this village has an emergency and needs to leave her baby for the day, she will easily find someone in this village she can trust with her baby (values 1 to 5).

4. Most of the people in my habitation are trustworthy and are honest (values 1 to 5 ).

The social capital metric is calculated by adding the scores of the four questions and dividing by the maximum score (25) to normalize it to a value between 0 and 1 . We made a selection of the questions from the survey and chose the questions above since they represent concrete questions related to trust and social capital. We expect that those with higher social capital (trust in others) would be less likely to overexploit groundwater.

In Model 2, we added total land owned and irrigated by tanks and wells to account for dependence on agriculture and irrigation, as well as knowledge of the resource (in the case of the area of groundwater irrigated).

\section{RESULTS}

The independent variables chosen to describe the characteristics theorized to affect cooperation in the games were summarized (Table 1). The average age of participants was $38.5 \mathrm{yr}$, with the men significantly older than the women: $42.9 \mathrm{yr}$ vs. $34.0 \mathrm{yr}$, respectively (Appendix 1). Education level varied among participants: $30 \%$ had not received any formal education, $26 \%$ had completed primary education, $34 \%$ had completed secondary school, and the remaining 10\% had completed higher levels of education such as intermediate school or university. Significant differences were also observed if we disaggregated the education data by gender. Only $15 \%$ of the men had not received any formal education in comparison with $45 \%$ of the women, and $35 \%$ of the men had completed primary school in comparison with $17 \%$ of the women. In higher levels of education, the differences between men and women were smaller, although the proportion of men that had received higher levels of education was higher: $38 \%$ of the men had completed secondary school vs. $31 \%$ of the women. This is consistent with the literacy rates of $74 \%$ for men and 54\% for women in Ananthapur District (http://www.ap.gov. in/districts/).

On average, each game was played for 9.12 rounds, with the shortest game lasting 4 rounds and the longest lasting 10 rounds (Appendix 1). Approximately $65 \%$ of the games were played for the maximum number of rounds (i.e., 10 rounds). On average, the games with communication were played for more rounds (9.44) than the games without communication $(8.79 ; P<0.001$, Wilcoxon Matched-Pairs Signed Ranks test). The level of water remaining at the end of the 10 rounds was not different before or after communication was allowed $(P=0.12$, Wilcoxon MatchedPairs Signed Ranks test), whereas the group income at the end of the game was higher in the game with communication $(P=0.045$, Wilcoxon Matched-Pairs Signed Ranks test). A closer look at the behavior of the players over the 10 rounds of the game shows that communication was particularly effective at the beginning and at the end of the game when, on average, players maximized their earnings (Fig. 2). Surprisingly, communication did not favor water conservation, although group earnings were higher when communication was allowed. Water use was greater in the rounds with communication (Fig. 3), although the differences were not significant. 
Fig. 2. Average earnings for the 34 participant groups in games without participant communication and with communication after each round.

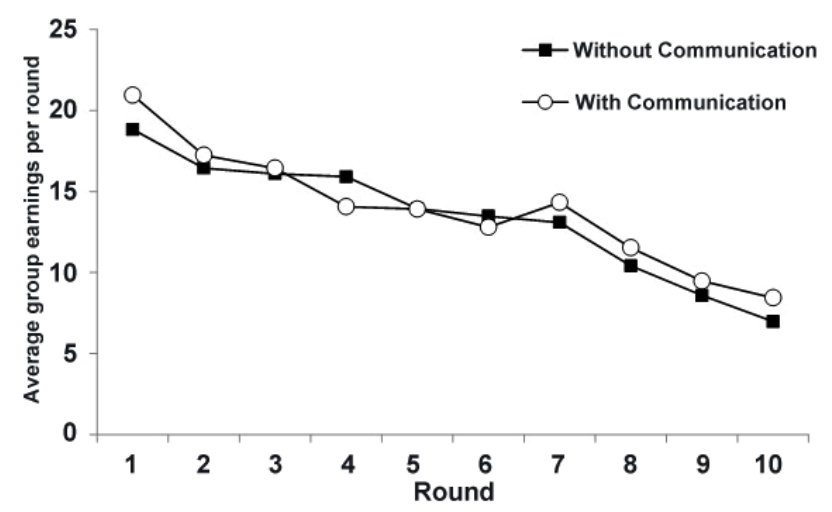

Fig. 3. Average amount of water remaining after extraction for the 34 participant groups in games without participant communication and with communication after each round.

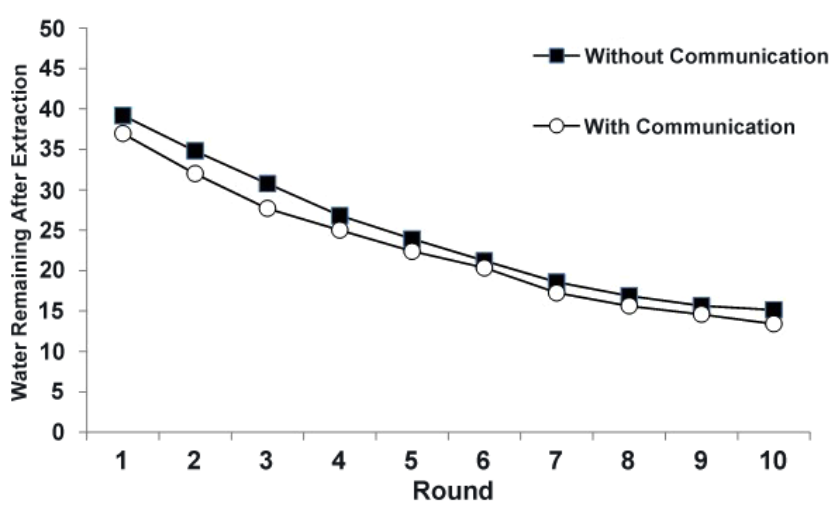

The groups earned between 97 and 160 units of income per game. Recall that the Nash equilibrium was 100 units and the social optimum was 166 units. The median group earnings were 136.5 units in treatment A (individual payments) and 140.5 units in treatment B (flat fee). This shows that, overall, the decisions were closer to the social optimum than the Nash equilibrium. The implication is that the groups were able to cooperate, even without communication.

In the communities where FES ran the experiments, participants earned an average of 136.4 units of income per game compared to 136.5 units in the communities where $\mathrm{J} \mathrm{J}$ ran the experiments. This is not significantly different $(P>0.1$, Mann-Whitney test). In both cases, communication led to a significant improvement in community earnings $(P<0.01$, Wilcoxon Matched-Pairs Signed Ranks test), with 140.4 units with communication and 137.4 units without it. This suggests that communication had a bigger influence in communities where FES was participating $(P$ $=0.095$, Mann-Whitney test). Contrary to expectations, we did not find any significant effects for gender or payment scheme.
Water use was highest when groundwater levels were near the maximum (Fig. 4). As groundwater levels were depleted, participants switched to the less water-intensive Crop A. This slowed the decline of the group groundwater levels but did not stabilize them.

Fig. 4. Average number of Crop B (intensive water use) per group for different levels of ground water available, in games without participant communication and with communication after each round.

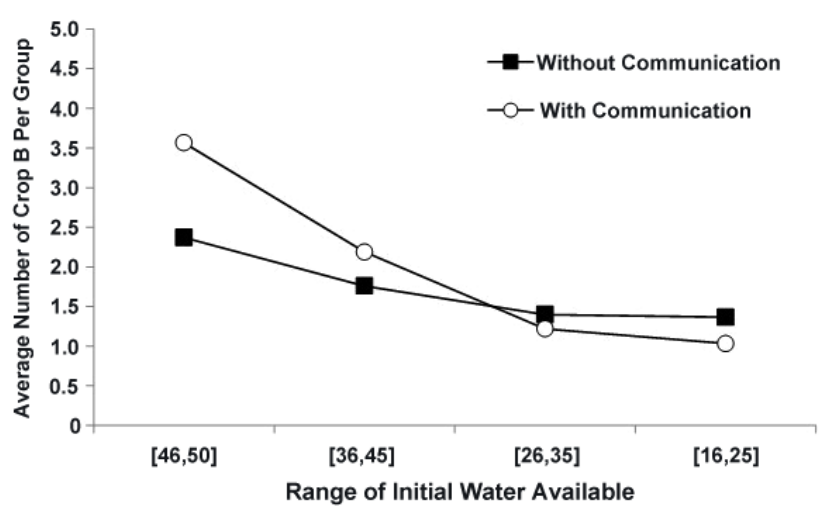

In the individual-payments treatment, the average payment per participant was Rs 273 (range: Rs 175-395). There were no significant differences between the behaviors of the participants in both treatments. The earnings of the flat-fee treatment (Rs 280; range: Rs 190-395) were essentially the same as those of the individual-payments treatment, suggesting that the game had equal salience to decision-making, whether or not players were paid cash based on the outcomes of their decisions.

In the individual- and group-level models, the individual and group-average water use were considered as the dependent variable (Table 2). Participants who reported stronger agreement with trust and social capital indicators in their communities used less water. This is consistent with theory because if a farmer refrains from using a water-consumptive but profitable crop to make the water table last longer, but his or her neighbors use the more water-consumptive crop, that farmer pays the price but does not get the benefit of stable water tables. However, those farmers who trust that their neighbors will help each other are more likely to believe that others will also cut back on water consumption and that a mutually beneficial situation can be achieved.

A notably strong effect on water usage was the length of time the villages were involved with NGOs. Both NGOs are working in adjoining watersheds with similar agroecological conditions and have similar practices in working with the communities in groundwater management, but JJ has been working with these communities on watershed management for 19 to $20 \mathrm{yr}$, whereas FES has been working with their communities for only $6 \mathrm{yr}$. JJ's relationships with their communities may be more deeply established, thus leading the members of these communities to a stronger understanding of groundwater problems and water governance. It is also possible that this result indicates an experimenter effect. The field teams received separate training, and because of the need for additional test sites in our project, 
Table 2. Individual- and group-level models for choice of water-consumptive crops.

\begin{tabular}{|c|c|c|c|c|}
\hline \multirow[b]{2}{*}{ Variable } & \multicolumn{2}{|c|}{ Individual-level models (logit) } & \multicolumn{2}{|c|}{ Group-level models (OLS) } \\
\hline & Model 1 & Model 2 & Model 3 & Model 4 \\
\hline Available water & $0.030 * *$ & $0.031 * *$ & $0.089 * *$ & $0.095 * *$ \\
\hline Flat-fee treatment & -0.060 & -0.133 & -0.139 & -0.119 \\
\hline Communication & 0.058 & 0.049 & 0.134 & 0.139 \\
\hline Round & $-0.139^{* *}$ & $-0.137 * *$ & $-0.208 * *$ & $-0.188 * *$ \\
\hline Years in program & $-0.056^{* *}$ & $-0.057 * *$ & $-0.128 * *$ & $-0.128 * *$ \\
\hline Female & -0.032 & -0.022 & -0.206 & -0.636 \\
\hline Age & -0.004 & -0.034 & $-0.048 * *$ & $-0.067 * *$ \\
\hline Caste & 0.077 & 0.070 & -0.144 & 0.121 \\
\hline Education & $-0.129 * *$ & $-0.133^{* *}$ & -0.198 & -0.309 \\
\hline Female $\times$ Education & $0.092 \dagger$ & 0.088 & 0.040 & 0.241 \\
\hline Household size & 0.005 & 0.004 & 0.096 & $0.243 \dagger$ \\
\hline Social capital & $-0.916^{*}$ & -0.691 & $-5.204 * *$ & $-5.861 * *$ \\
\hline Area owned & & $-0.082 *$ & & -0.032 \\
\hline Area tank-irrigated & & $0.294 \dagger$ & & 0.038 \\
\hline Area groundwater-irrigated & & $0.208 * *$ & & $0.246^{*}$ \\
\hline Constant & 0.484 & 0.413 & $14.260^{* *}$ & $13.312 * *$ \\
\hline$N$ & 3054 & 2910 & 620 & 620 \\
\hline Akaike Information Criterion & 3575.789 & 3404.210 & 2936.475 & 2933.551 \\
\hline Log-likelihood/R ${ }^{2}$ & -1774.895 & -1686.105 & 0.295 & 0.305 \\
\hline
\end{tabular}

$* P<0.05, * * P<0.01 ; \dagger P<0.1$. Significance level derived from robust standard errors.

the $\mathrm{JJ}$ team was recruited and trained at a later date, potentially receiving less background on field experiment principles and protocols compared to the FES field team. However, the long history of $\mathrm{JJ}$ work in the communities seems to be a stronger explanation for these results.

The water-use control variable, i.e., water availability at the beginning of each round, was highly significant, as expected: the higher the water table at the beginning of the round, the more water was used in that round (Fig. 4). This is a rational response because as long as water is abundant, participants might as well profit from it, but when participants see water tables start to fall, they consider reducing water use to ensure that the resource lasts.

Contrary to expectations, gender did not have a significant effect on crop choice. However, higher education led to lower water use in the game, and women have a significantly lower education level than men $(P<0.001$, t-test; Appendix 1). An interaction effect between education and gender was only marginally significant in Model 1. Although gender is not significant after controlling for education, the fact that women, on average, chose more waterconsumptive crops is somewhat surprising. Women are primarily responsible for domestic water use and are therefore most affected when the water table falls and domestic water wells in the villages go dry. Follow-up qualitative research indicated that women associate the failure of domestic water wells with low rainfall and not with groundwater use for irrigation. A second factor may also be at work: women's time constraints. Although the teams tried to schedule the women's games at a convenient time, it was difficult for women to set aside the time for the full game session. Thus, some of the women's groups were willing to deplete the groundwater more rapidly to end the game and return to family responsibilities. This indicates the need to be aware of other factors that may affect the way people make choices in experimental games.

Farmers with larger land holdings were significantly less likely to choose water-consumptive crops. This may mean that those with large total land holdings can cultivate larger areas under watersaving crops rather than depending on more profitable but more water-intensive crops. Landowners with more lands might be more familiar with the connection of groundwater levels and crop choice. However, those who have more land under tank or groundwater irrigation are more likely to choose the waterconsumptive crops in the game, which may reflect their own farming practices and familiarity with higher value crops.

With all other variables held constant, communication did not have a significant effect on water use, compared to the first 10 rounds without communication. A possible reason for the lack of effect on collective crop choice is the familiarity of the participants with each other and the context of the game. Chat between the participants may not affect expectations of the actions of others nor contribute to a better understanding of the experiment.

Other measured demographic features had very little effect on crop choice. Age was only significant at the group level, and neither caste nor household size had a significant effect at the individual level.

We observed no effect of payment method used in each community. This is a surprising result from the perspective of experimental economics theory, which predicts the payment and its salience to the subjects is a significant factor in motivating realistic behavior (Hoffman et al. 1996). Respondents did not play the game differently if they were playing for real money or simply for imaginary payments. This calls into question the premise of many field experiments that payments based on outcomes of the game are necessary to simulate commons dilemmas (Smith and Walker 1993). It is possible that the participants might not have perceived the payments as significant or have been affected by them as strongly as other motivations or priorities during the game session. More research is needed to understand better how participants perceive the game experience and how they prioritize individual monetary incentives vs. other goals they may hold. 


\section{CONCLUSION}

We performed experimental games on crop choice and groundwater use in 17 habitations of Andhra Pradesh, India. The groundwater situation in Andhra Pradesh is delicate because groundwater is the main source of water for many households, and many aquifers in the state are overexploited and wells are running dry. A common-pool resource game was used to observe how people make decisions about groundwater use and to understand which factors influence people's decisions related to groundwater management.

The first important finding is that participants do consider group interests, not only their individual interests, in the game. Almost $65 \%$ of the games were played for the maximum number of rounds, which suggests that group gains and groundwater conservation were pursued by most participants when the links were explained to them in the game. This is consistent with what is found in other field experiments regarding the use of commonpool resources (e.g., Cardenas and Carpenter 2008, Janssen et al. 2012, Cardenas et al. 2013).

If such levels of cooperation are found in the game, why is it that groundwater levels are being depleted in practice? One factor may be that the game makes explicit the links between crop choice, collective action, and groundwater levels. Many farmers reported in the debriefing sessions that they had thought that groundwater levels were mostly affected by rainfall, and they had not understood the effect of their crop choice on water table levels. In this sense, the experimental games provided the basis for social leaning about groundwater and the scope for collective responses to arrest falling water tables. This is not to say that the games themselves, or the debriefing sessions, are sufficient to change the trajectory of groundwater levels. However, they can provide an important complement to other interventions for communitybased groundwater management.

The individual water-use level is partly explained by social capital: consistent with theory (e.g., Agrawal 2001), those participants reporting the highest social capital in their community used less water. Those who trust their neighbors are more likely to make cooperative choices, which can improve the sustainability of the resource. This finding can have important policy implications, indicating the value of programs that promote collective action and community cooperation for the governance of groundwater resources. There was a considerable difference in crop choices between the communities facilitated by the two NGOs, with participants choosing less water consumption where the NGO had been working for a longer time. This increases our confidence that choices in the game reflect, in some way, choices in practice because the communities where the NGO has worked longest would be more likely to understand the importance of crop choice and overcome groundwater dilemmas.

Two variables that did not have a significant effect are particularly important: gender and payment scheme. The fact that women were not more likely to limit water-consumptive crops to maintain the groundwater levels was surprising, given that women are most responsible for domestic water, which becomes scarcer when water tables fall. The structure of the game did not include explicit linkages between irrigation and domestic water availability. It is possible that if this had been included, women would have shown more concern about falling water tables. Further exploration of gender differences in understanding of the game, perceptions of groundwater dynamics, and roles in crop choice would be needed to explain these patterns.

The lack of significant difference between individual payments and flat-fee compensation to the watershed committee has methodological relevance for future experimental games design. Our games appear to be equally salient to the intrinsically motivated farmers, whether or not they are paid cash based on the simulated earnings in the game (Gneezy et al. 2011). However, we find that the decisions are in line with actual behavior of individuals, such as higher water use by those who have more groundwater irrigation and higher water use when groundwater levels are higher. If payment does not affect how people respond in such games, it could expand the possibilities of using framed field experiments in situations where it is inappropriate to pay participants. However, serious consideration should be given to what effect these games have on participants. In the case of these groundwater activities, the games can actually have beneficial effects in making farmers aware of how their crop choices affect water tables and in stimulating discussions on what farmers can do to regulate groundwater use. The games can therefore be a valuable complement to government or NGO activities.

Experimental games do not always reflect how people behave in practice, but they do provide insights on factors that affect their choices. More research is needed to understand some of the surprising findings such as the lack of effect of individual monetary incentives and the lack of a gender effect. However, we found a remarkable effect associated with how long the communities had been involved with NGO participatory management projects. Future research will focus on solicitation of mental models to derive a better understanding of how participants see the relationship between crop choice, groundwater use, and the performance of the community to help assist government and NGO programs identify the factors that contribute to community management of groundwater resources.

\section{Responses to this article can be read online at:} http://www.ecologyandsociety.org/issues/responses. $\mathrm{php} / 8416$

\section{Acknowledgments:}

This work was undertaken as part of the CGIAR Research Program on Water, Land and Ecosystems (WLE), Colombo, Sri Lanka. We thank all donors who supported this research through their contributions to the CGIAR Fund. Jagdeesh Puppala Rao, Juan Camilo Cardenas, Claudia Ringler, Bryan Bruns, and Andrew Bell provided valuable advice and comments. We thank the field staff of the Foundation for Ecological Security, in particular field associates K. P. Sriramulu and Ms. S. K. Arhiya. We also mention a special word of gratitude to the management and staff of Jana Jagriti, Tanakallu Office; in particular, Mr. D. P. Balaram, CEO; Mr. S. Srinivas Reddy, Project Coordinator; and Mr. Lakshmana Murthy, Social Mobilizer. Finally, we thank the men and women from the participating communities in the villages of NP Kunta and Tanakallu Mandals. 


\section{LITERATURE CITED}

Agrawal, A. 2001. Common property institutions and sustainable governance of resources. World Development 29(10):1649-1672. http://dx.doi.org/10.1016/S0305-750X(01)00063-8

Anderies, J. M., M. A. Janssen, F. Bousquet, J.-C. Cardenas, D. Castillo, M.-C. Lopez, R. Tobias, B. Vollan, and A. Wutich. 2011. The challenge of understanding decisions in experimental studies of common pool resource governance. Ecological Economics 70 (9):1571-1579. http://dx.doi.org/10.1016/j.ecolecon.2011.01.011

Baland, J.-M., and J.-P. Platteau. 1996. Halting degradation of natural resources: is there a role for rural communities? Food and Agriculture Organisation, Rome, Italy. [online] URL: http://www. fao.org/docrep/x 5316e/x5316e00.htm

Bardhan, P. 1993. Analytics of the institutions of informal cooperation in rural development. World Development 21 (4):633-639. http://dx.doi.org/10.1016/0305-750X(93)90115-P

Bekkar, Y., M. Kuper, M. Errahj, N. Faysse, and M. Gafsi. 2009. On the difficulty of managing an invisible resource: farmers' strategies and perceptions of groundwater use, field evidence from Morocco. Irrigation and Drainage 58(S3):S252-S263. http://dx. doi.org/10.1002/ird.527

Blomquist, W. 1992. Dividing the waters: governing groundwater in southern California. ICS Press, San Francisco, California, USA.

Cardenas, J.-C. 2000. How do groups solve local commons dilemmas? Lessons from experimental economics in the field. Environment, Development and Sustainability 2(3-4):305-322. http://dx.doi.org/10.1023/A:1011422313042

Cardenas, J. C. and J. Carpenter. 2008. Behavioural development economics: lessons from field labs in the developing world. Journal of Development Studies 44(3):311-338. http://dx.doi. org/10.1080/00220380701848327

Cardenas, J.-C., M. Janssen, and F. Bousquet. 2013. Dynamics of rules and resources: three new field experiments on water, forests and fisheries. Pages 319-345 in J. A. List and M. K. Price, editors. Handbook on experimental economics and the environment. Edward Elgar, Cheltenham, UK.

Cardenas, J. C., J. Stranlund, and C. Willis. 2000. Local environmental control and institutional crowding out. World Development 28(10):1719-1733. http://dx.doi.org/10.1016/S0305-750X (00)00055-3

Central Ground Water Board. 2012. Groundwater brochure: Anantapur District, Andhra Pradesh. Ministry of Water Resources, Government of India, Hyderabad, India. [online] URL: http://cgwb.gov.in/District_Profile/AP/Ananthapur.pdf

Central Ground Water Board. 2013. Ground water year book India 2012-13. Ministry of Water Resources, Government of India, Faridabad, India. [online] URL: http://www.

indiaenvironmentportal.org.in/content/385809/ground-water-yearbook-india-2012-13/

Faysse, N. and O. Petit. 2012. Convergent readings of groundwater governance? Engaging exchanges between different research perspectives. Irrigation and Drainage 61(S1):106-114. http://dx.doi.org/10.1002/ird.1654
Faysse, N., J.-D. Rinaudo, S. Bento, A. Richard-Ferroudji, M. Errahj, M. Varanda, A. Imache, M. Dionnet, D. Rollin, P. Garin, M. Kuper, L. Maton, and M. Montginoul. 2014. Participatory analysis for adaptation to climate change in Mediterranean agricultural systems: possible choices in process design. Regional Economic Change 14 (S1):57-70. http://dx.doi.org/10.1007/ s10113-012-0362-X

Fehr, E., and S. Gächter. 2000. Cooperation and punishment in public goods experiments. American Economic Review 90 (4):980-994. http://dx.doi.org/10.1257/aer.90.4.980

Gardner, R., M. R. Moore, and J. M. Walker. 1997. Governing a groundwater commons: a strategic and laboratory analysis of Western water law. Economic Inquiry 35(2):218-234. http://dx.doi. org/10.1111/j.1465-7295.1997.tb01905.x

Garduño, H., S. Foster, P. Raj, and F. van Steenbergen. 2009. Addressing groundwater depletion through community-based management actions in the weathered granitic basement aquifer of drought-prone Andhra Pradesh - India. Sustainable Groundwater Management Lessons from Practice Case 19. World Bank, Washington, D.C., USA. [online] URL: http://documents. worldbank.org/curated/en/2009/04/11416251/addressing-groundwaterdepletion-through-community-based-management-actions-weatheredgranitic-basement-aquifer-drought-prone-andhra-pradesh-india

Gneezy, U., S. Meier, and P. Rey-Biel. 2011. When and why incentives (don't) work to modify behavior. Journal of Economic Perspectives 25(4):191-210. http://dx.doi.org/10.1257/jep.25.4.191

Henrich, J., J. Ensminger, R. McElreath, A. Barr, C. Barrett, A. Bolyanatz, J. C. Cardenas, M. Gurven, E. Gwako, N. Henrich, C. Lesorogol, D. Marlowe, D. Tracer, and J. Ziker. 2010. Markets, religion, community size, and the evolution of fairness and punishment. Science 327:1480-1484. http://dx.doi.org/10.1126/ science. 1182238

Herr, A., R. Gardner, and J. M. Walker. 1997. An experimental study of time-independent and time-dependent externalities in the commons. Games and Economic Behavior 19(1):77-96. http:// dx.doi.org/10.1006/game.1997.0541

Herrmann, B., C. Thöni, and S. Gächter. 2008. Antisocial punishment across societies. Science 319:1362-1367. http://dx. doi.org/10.1126/science. 1153808

Hoffman, E., K. A. McCabe, and V. L. Smith. 1996. On expectations and the monetary stakes in ultimatum games. International Journal of Game Theory 25(3):289-301. http://dx. doi.org/10.1007/BF02425259

Janssen, M. A., and J. M. Anderies. 2011. Governing the commons: learning from field and laboratory experiments. Ecological Economics 70(9):1569-1570. http://dx.doi.org/10.1016/ j.ecolecon.2011.03.023

Janssen, M. A., F. Bousquet, J.-C. Cardenas, D. Castillo, and K. Worrapimphong. 2012. Field experiments on irrigation dilemmas. Agricultural Systems 109:65-75. http://dx.doi.org/10.1016/j. agsy.2012.03.004

Janssen, M. A., R. Holahan, A. Lee, and E. Ostrom. 2010. Lab experiments for the study of social-ecological systems. Science 328:613-617. http://dx.doi.org/10.1126/science.1183532 
Kemper, K. E. 2007. Instruments and institutions for groundwater management. Pages 153-172 in M. Giordano and K. G. Villholth, editors. The agricultural groundwater revolution: opportunities and threats to development. CABI, Wallingford, UK.

Kumar, M. D., M. V. K. Sivamohan, V. Niranjan, and N. Bassi. 2011. Groundwater management in Andhra Pradesh: time to address real issues. Occasional Paper 4-0211. Institute for Resource Analysis and Policy, Hyderabad, India. [online] URL: http://www.indiawaterportal.org/sites/indiawaterportal.org/files/ Groundwater management in Andhra Pradesh IRAP 2011.pdf

Kuper, M., M. Dionnet, A. Hammani, Y. Bekkar, P. Garin, and B. Bluemling. 2009. Supporting the shift from state water to community water: lessons from a social learning approach to designing joint irrigation projects in Morocco. Ecology and Society 14(1):19. [online] URL: http://www.ecologyandsociety. org/vol14/iss1/art19/

Lecoutere, E., B. D'Exelle, and B. Van Campenhout. 2015. Sharing common resources in patriarchal and status-based societies: evidence from Tanzania. Feminist Economics 21 (3):142-167. http://dx.doi.org/10.1080/13545701.2015.1024274

Meinzen-Dick, R., K. V. Raju, and A. Gulati. 2002. What affects organization and collective action for managing resources? Evidence from canal irrigation systems in India. World Development 30(4):649-666. http://dx.doi.org/10.1016/s0305-750x (01)00130-9

Mitchell, M., A. Curtis, E. Sharp, and E. Mendham. 2011. Social research to improve groundwater governance: a literature review. Report 66. Institute for Land, Water and Society, Charles Sturt University, Albury, Australia. [online] URL: https://www.csu. edu.au/ data/assets/pdf file/0006/702843/66 Groundwater lit review Nov -2011.pdf

Moxnes, E. 1998a. Not only the tragedy of the commons: misperception of bioeconomics. Management Science 44 (9):1234-1248.

Moxnes, E. 1998b. Overexploitation of renewable resources: the role of misperceptions. Journal of Economic Behavior and Organization 37(1):107-127. http://dx.doi.org/10.1016/S0167-2681 (98)00079-1

Mukherji, A. 2006. Political ecology of groundwater: the contrasting case of water-abundant West Bengal and water-scarce Gujarat, India. Hydrogeology Journal 14(3):392-406. http://dx. doi.org/10.1007/s10040-005-0007-y

Mukherji, A., and T. Shah. 2005. Groundwater socio-ecology and governance: a review of institutions and policies in selected countries. Hydrogeology Journal 13(1):328-345. http://dx.doi. org/10.1007/s10040-005-0434-9

Olson, M. 1965. The logic of collective action: public goods and the theory of groups. Harvard University Press, Cambridge, Massachusetts, USA.

Ostrom, E. 1965. Public entrepreneurship: a case study in ground water basin management. Dissertation. University of California, Los Angeles, California, USA. [online] URL: https://dlc.dlib. indiana.edu/dlc/bitstream/handle/10535/3581/eostr001.pdf?sequence=1
Ostrom, E. 1990. Governing the commons: the evolution of institutions for collective action. Cambridge University Press, Cambridge, UK.

Ostrom, E., J. Burger, C. B. Field, R. B. Norgaard, and D. Policansky. 1999. Revisiting the commons: local lessons, global challenges. Science 284:278-282. http://dx.doi.org/10.1126/ science.284.5412.278

Ostrom, E., R. Gardner, and J. Walker. 1994. Rules, games and common-pool resources. University of Michigan Press, Ann Arbor, Michigan, USA.

Pahl-Wostl, C., M. Craps, A. Dewulf, E. Mostert, D. Tabara, and T. Taillieu. 2007. Social learning and water resources management. Ecology and Society 12(2):5. [online] URL: http:// www.ecologyandsociety.org/vol12/iss2/art5/

Pahl-Wostl, C., E. Mostert, and D. Tàbara. 2008. The growing importance of social learning in water resources management and sustainability science. Ecology and Society 13(1):24. [online] URL: http://www.ecologyandsociety.org/vol13/iss1/art24/

Poteete, A. R., M. A. Janssen, and E. Ostrom. 2010. Working together: collective action, the commons, and multiple methods in practice. Princeton University Press, Princeton, New Jersey, USA.

Prediger, S., B. Vollan, and M. Frölich. 2011. The impact of culture and ecology on cooperation in a common-pool resource experiment. Ecological Economics 70(9):1599-1608. http://dx.doi. org/10.1016/j.ecolecon.2010.08.017

Reddy, V. R., M. S. Reddy, and S. K. Rout. 2014. Groundwater governance: a tale of three participatory models in Andhra Pradesh, India. Water Alternatives 7(2):275-297.

Ross, A., and P. Martinez-Santos. 2010. The challenge of groundwater governance: case studies from Spain and Australia. Regional Environmental Change 10(4):299-310. http://dx.doi. org/10.1007/s10113-009-0086-8

Rukmini, R., and M. Manjula. 2009. Designing rural technology delivery systems for mitigating agricultural distress: a study of Anantapur District. MS Swaminathan Research Foundation, Chennai, and Office of the Principal Scientific Adviser to the Government of India, New Delhi, India. [online] URL: http:// www.psa.gov.in/sites/default/files/12723828131_StudyofAnantapur. pdf

Rustagi, D., S. Engel, and M. Kosfeld. 2010. Conditional cooperation and costly monitoring explain success in forest commons management. Science 330:961-965. http://dx.doi. org/10.1126/science.1193649

Salcedo Du Bois, R. 2014. Groundwater games: users' behavior in common-pool resource economic laboratory and field experiments. Dissertation. Pennsylvania State University, State College, Pennsylvania, USA.

Schlager, E. 2007. Community management of groundwater. Pages 131-152 in M. Giordano and K. G. Villholth, editors. The agricultural groundwater revolution: opportunities and threats to development. CABI, Wallingford, UK. http://dx.doi. org/10.1079/9781845931728.0131 
Siebert, S., J. Burke, J. M. Faures, K. Frenken, J. Hoogeveen, P. Döll, and F. T. Portmann. 2010. Groundwater use for irrigation a global inventory. Hydrology and Earth System Sciences 14 (10):1863-1880. http://dx.doi.org/10.5194/hess-14-1863-2010

Shah, T. 2009. Taming the anarchy: groundwater governance in South Asia. Resources for the Future, Washington, D.C., USA and IWMI, Colombo, Sri Lanka.

Shah, T., M. Giordano, and A. Mukherji. 2012. Political economy of the energy-groundwater nexus in India: exploring issues and assessing policy options. Hydrogeology Journal 20(5):995-1006. http://dx.doi.org/10.1007/s10040-011-0816-0

Smith, V. L., and J. M. Walker. 1993. Monetary rewards and decision cost in experimental economics. Economic Inquiry 31 (2):245-261. http://dx.doi.org/10.1111/j.1465-7295.1993.tb00881. $\underline{\mathrm{x}}$

Suter, J. F., J. M. Duke, K. D. Messer, and H. A. Michael. 2012. Behavior in a spatially explicitly groundwater resource: evidence from the lab. American Journal of Agricultural Economics 94 (5):1094-1112. http://dx.doi.org/10.1093/ajae/aas058

van Steenbergen, F. 2006. Promoting local management in groundwater. Hydrogeology Journal 14(3):380-391. http://dx.doi. org/10.1007/s10040-005-0015-y

Vollan, B. 2008. Socio-ecological explanations for crowding-out effects from economic field experiments in southern Africa. Ecological Economics 67(4):560-573. http://dx.doi.org/10.1016/j. ecolecon.2008.01.015

World Bank. 2010. Deep wells and prudence: towards pragmatic action for addressing groundwater overexploitation in India. World Bank, Washington, D.C., USA. [online] URL: http://documents. worldbank.org/curated/en/2010/01/11899840/deep-wells-prudencetowards-pragmatic-action-addressing-groundwater-overexploitationindia 


\section{Appendix 1. Protocol for Experimental Game, Survey, and Community Debriefing}

\section{Groundwater Field Experiment Protocol}

[FACILITATOR: Make sure everyone is sitting and not distracted by other matters. Read aloud, from the script, and always alert to any questions; be alert for facial expressions of the participants to detect lack of understanding of the activity. ${ }^{1}$

\section{Instructions to read to the participants}

Hello, I am ___ from FES. As a part of our hydrology project, we want to understand how you make your decisions on what crops to plant. This is a voluntary experience for you to help us to understand what you do. In case there is something you do not understand during the instructions, we invite you to raise your hand and we will be glad to respond to any question. We ask you to turn off your mobile phones to avoid any distractions during the activity. You are free to leave any time you wish, however if you leave, this session will end for everyone else also.

The types of crops that you choose to plant affect how much groundwater is used and how much money you make. We all know that crops like paddy and sugar cane require more water to grow than crops like groundnut and ragi, but paddy and sugar cane also can fetch more income than groundnut and ragi. Isn't that so?

So, if everyone grows paddy or sugar cane, then the groundwater levels are likely to fall more than if everyone grows groundnut or ragi. Does that make sense?

\section{[Wait for responses]}

We are going to play an activity that looks at how people make these decisions of what crops to plant. This is not a test; it is just an opportunity for you to make decisions just like you do all the time. But in this situation, you will be playing through several years of planting crops in a short period of time. This activity is very simple, and it doesn't include all the things that you usually deal with in your fields. We are just focusing on the rabi season, which depends only on boru (groundwater). And we are focusing on how you decide between planting one or two different kinds of crops. They are not actual crops that you use; they are pretend crops. One requires a little amount of water to grow and it gives you a small amount of money. We will call that Crop A. The other crop requires more water to grow but gives you more money. We will call that Crop B.

[ONLY for the Individual Payments treatment:] You will be paid cash at the end of this session based on the crops you choose to plant.

\footnotetext{
${ }^{1}$ Text highlighted in gray are instructions for the experimenters.
} 


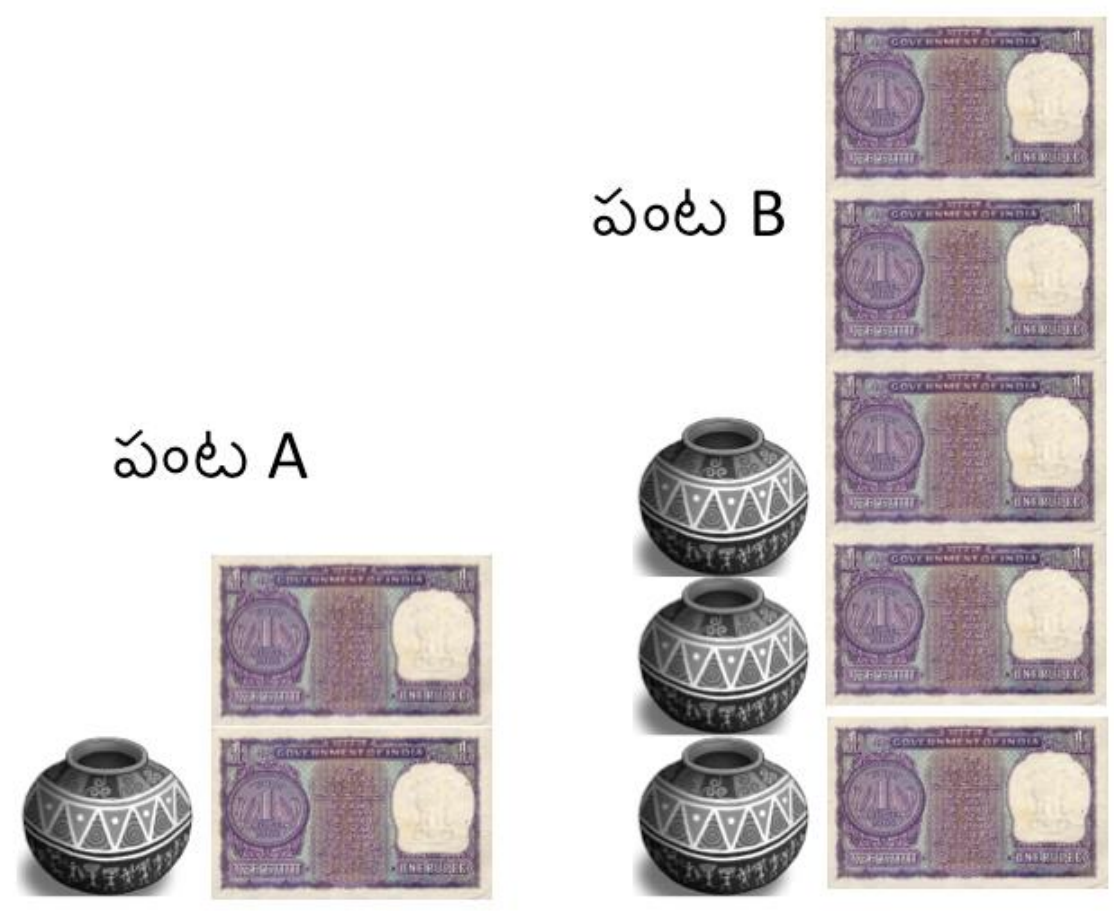

Figure 1. Crop A/B Comparison

\section{Any Questions? [Wait for any questions]}

We will begin by playing an activity. After we have finished playing the activity, we will have a discussion period to allow you to talk about the activity and your thoughts. When we have completed our discussion, we will play the activity again so you can try out the ideas that you may have talked about. During the first activity, you are asked not to speak; we also ask that you not tell other people in the village about this activity until the community meeting. During the second activity, you will have 45 seconds to talk after each year to discuss your plans.

This activity is intended to recreate the situation in which people must make decisions about using water to grow crops. You have been organized into a group of five individuals. You will play a number of years, which have one pretend growing season, when all your water comes from groundwater. Though each of you may have different amounts of land, for this activity you should pretend that you all have the same amount of land, say 1 hectare.

At the beginning of the activity, there are 50 units of groundwater available for your group to grow crops. The amount of groundwater available is shown on the board as blue water in a bore well. As water is used, we will move the blue column down to show you how much groundwater is remaining. Every year, you will have to make a decision, which of the two crops to plant: Crop A or Crop B. Crop A costs one unit of water and gives two units of income. Crop B costs three units of water and gives five units of income. At the beginning of each year, the groundwater supply recharges by 5 units of water. We will show this recharge happen by moving the blue column up by 5 units of water in the bore well. 


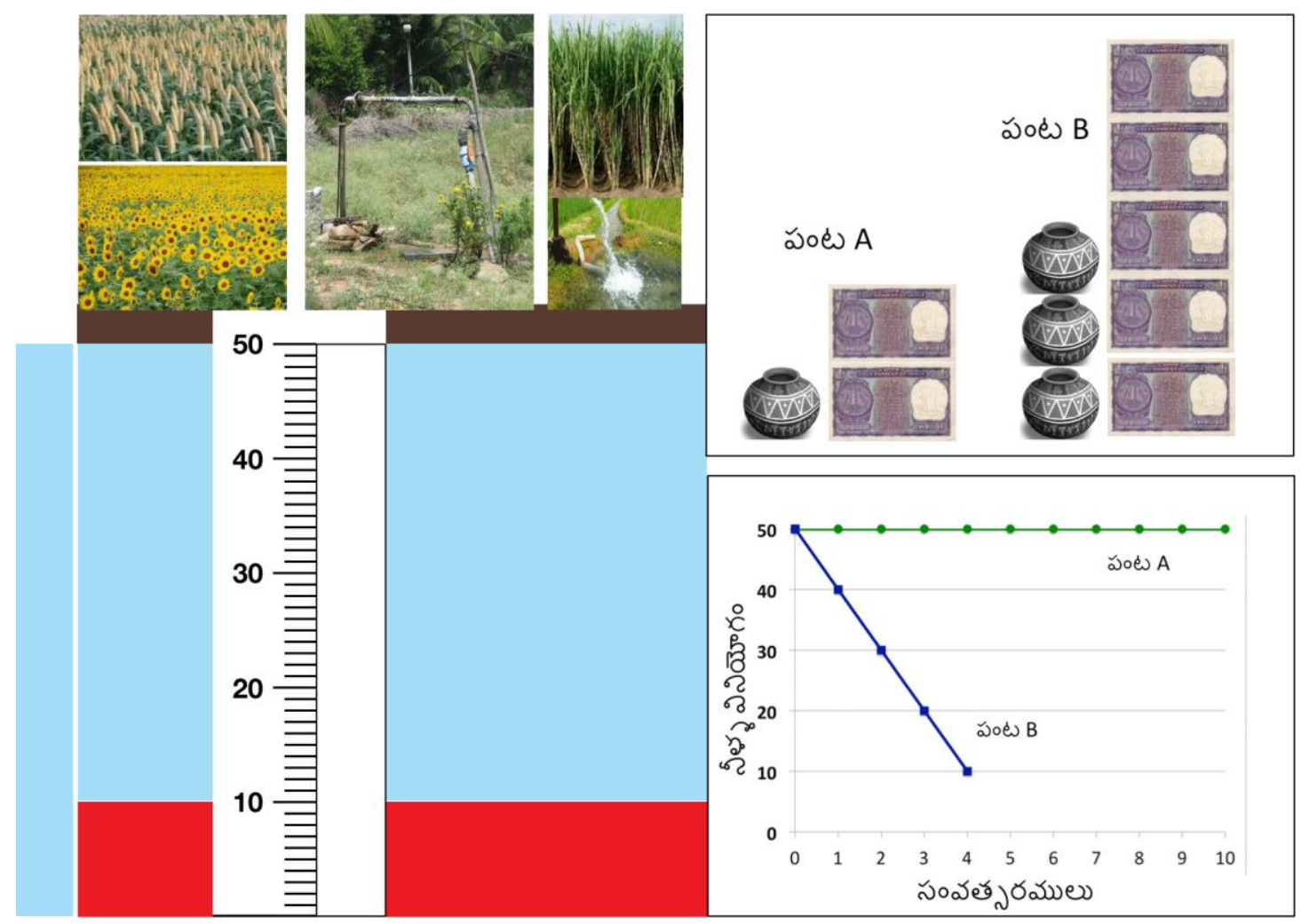

Figure 2. Water Level Indicator

So looking at our picture of a bore well, if everyone plants crop A, 5 units of water will be used, leaving 45 units of water. At the beginning of the next round, the groundwater will recharge with 5 units of water, so there will be 50 units of water available for the group.

If everyone plants crop B, 15 units of water will be used, leaving 35 units of water. At the beginning of the next round, the groundwater will recharge with 5 units of water, so there will be 40 units of water available.

If some people choose Crop A and others choose Crop B, then the amount of water that will be used will between these two possibilities.

[ONLY for the Individual Payments treatment, state:] At the end of the game, we will pay you Rs 5 for every unit of money you earn in this game. So if you earn 20 units of money in the game, we will give you 100 rupees. We will give you your earnings in private, so that no one else knows how much you made.

We will play the activity for a number of years. If the groundwater level drops below 10 units of water, which is marked here with this red line, for simplicity's sake, the activity is ended due to insufficient water for the group.

When the activity is ended, we will begin a discussion period, where you can talk about the activity, and share any thoughts or observations you may have about your experience. After the 
discussion session, we will play the activity again, starting with a fresh groundwater supply of 50 units.

I will now describe how we will play the activity in detail. We are handing each of you a piece of paper, your Decision Form. Each year, you will choose which crop to plant by circling one of the two options in the "My Crop" column. Circle "A" if you want to plant crop A, or circle "B" if you want to plant crop B. We will come around to record which crop you want to plant, and we will write how much income you receive for your crops in your Income column. Hold the Decision Form in your hand so only we can see which crop you have chosen to plant.

\begin{tabular}{|c|c|c|c|}
\hline \multicolumn{4}{|c|}{ Declsion Form } \\
\hline \multicolumn{4}{|c|}{ Participant: 1} \\
\hline WS: & \multicolumn{2}{|l|}{ Vill: } & $\mathrm{HU}$ : \\
\hline Group: $1 / 2$ & \multicolumn{2}{|c|}{ Game: 1} & \\
\hline & \multicolumn{2}{|c|}{ My Crop } & My Income \\
\hline Practice & A & B & \\
\hline \multirow[t]{14}{*}{ Practice } & A & B & \\
\hline & A & $\mathrm{B}$ & \\
\hline & A & B & \\
\hline & A & B & \\
\hline & $\mathrm{A}$ & $\mathrm{B}$ & \\
\hline & A & $\mathrm{B}$ & \\
\hline & A & B & \\
\hline & $\mathrm{A}$ & $\mathrm{B}$ & \\
\hline & A & $\mathrm{B}$ & \\
\hline & A & $\mathrm{B}$ & \\
\hline & A & $\mathrm{B}$ & \\
\hline & A & B & \\
\hline & A & $\mathrm{B}$ & \\
\hline & A & $\mathrm{B}$ & \\
\hline
\end{tabular}

\section{Figure 3. Participant Decision Form (also shown in large-format to participants for instruction)}

We will calculate how much water the group has used, and we will move the blue column down to show you how much groundwater remains. This is the end of the year.

At the beginning of the next year, we will move the blue column up by 5 units of water to show you the groundwater recharge and announce how much groundwater is available to your group. 
So for example, if everyone were to plant Crop A every round, the groundwater supply will fully recharge every round. Each participant would earn a total of 20 units of income from their crops.

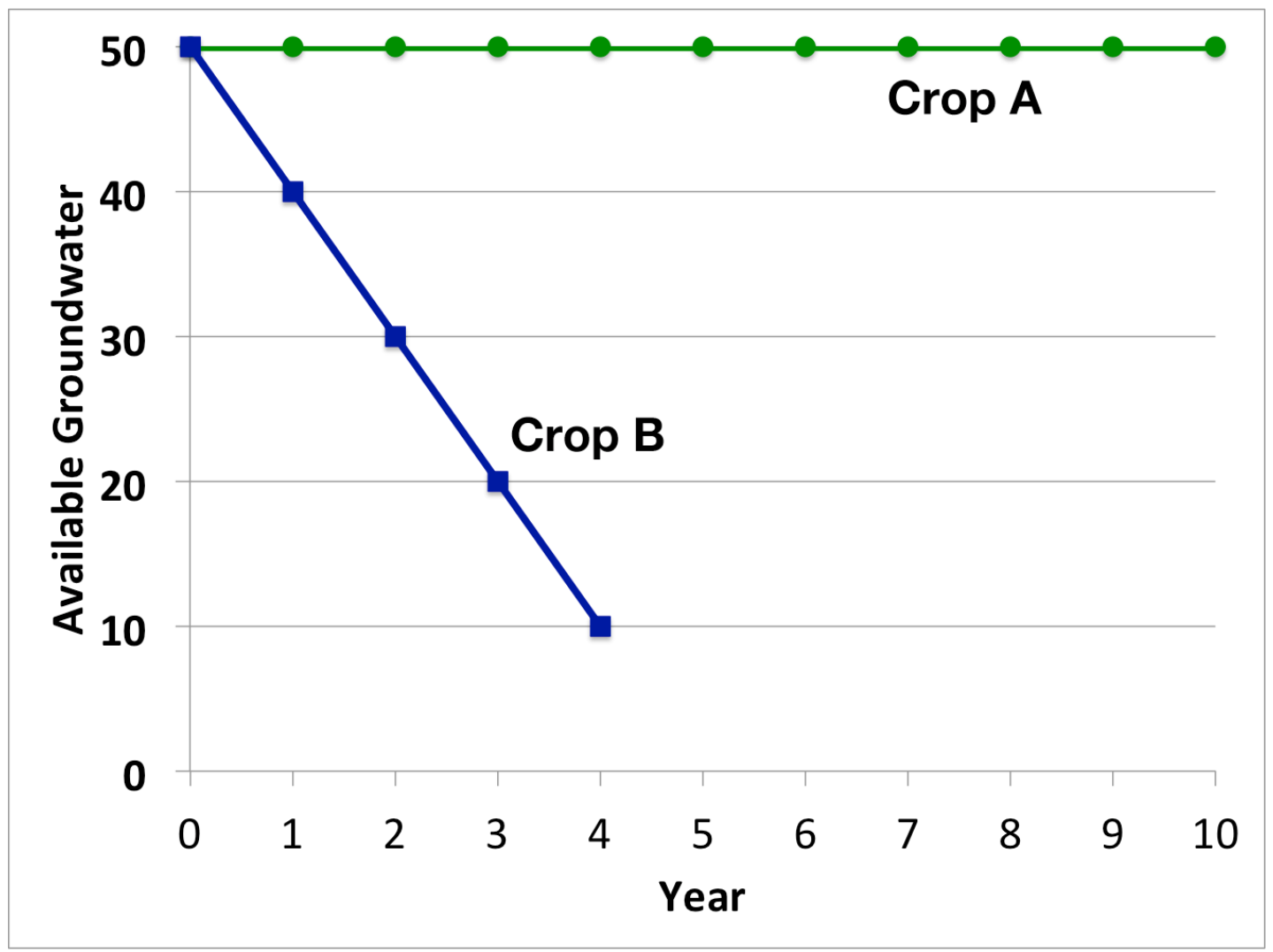

Figure 4. Comparison of Everyone Playing A vs Everyone Playing B (AAAAA vs BBBBB)

If everyone plants Crop B every round, the groundwater supply would last for 5 rounds. Each participant would earn 25 units of income from their crops.

Keep in mind that your decisions are private, and everyone can decide for themselves which crop they wish to plant each round. This means when you show us your Decision Form, only we see the crops you circled on your form.

Do you have any questions about this? [FACILITATOR: pause to resolve questions.]

Keep in mind that from now on you are not allowed to talk to each other until we tell you it is ok for you to do so.

First, we will play three practice years that will not count toward the results of the groundwater levels. These practice rounds are just an opportunity for you familiarize yourself with the activity.

After we have completed the practice years, you will have another opportunity to ask any questions you may have. After that, we will begin the actual activity. 


\section{Practice Year:}

[FACILITATOR: If this is the second practice round, add 5 units of water to the groundwater diagram.]

This is the beginning of a new practice year. [5 units of groundwater have recharged. $]^{2}$ There are units of groundwater available. Please make your decision on which crop you will plant for this round, Crop A or Crop B. Please carefully show your Decision Form to the monitor when they come to you.

[MONITOR: Write down each participant's crop decision on the Monitor Form. Calculate the amount of water used, and the remaining water. Show these numbers to the Facilitator.]

For the practice years only, we are going to tell you how many people chose to plant crop A and crop B, so you can tell us how many units of water was used, and how many units of income each person received.

people chose to plant Crop A, and people chose to plant Crop B.

How many units of water have been used?

How many units of income do the people who planted Crop A receive?

How many units of income do the people who planted Crop B receive?

[FACILITATOR: If this is not the last practice round, return to the beginning of the practice round instructions above. Otherwise, continue to the Beginning of the actual activity rounds below.]

[That was the last practice year. Do you have any questions?]

[Look for any questions]

[We will now reset the groundwater level to 50 units of water and begin the real exercise.]

\footnotetext{
${ }^{2}$ Text underlined inside brackets is conditional. Only recite this text if it applies to the current status of the activity (as in there is recharge for years following the first year.) Skip it if it doesn't apply now.
} 


\section{ACTIVITY 1: YEARS WITHOUT COMMUNICATION}

[FACILITATOR: If this is round 2 or later, add 5 units of water to the groundwater diagram.]

This is the beginning of a new practice year. [5 units of groundwater have recharged.] There are units of groundwater available. Please make your decision on which crop you will plant for

this round, Crop A or Crop B. Please carefully show your Decision Form to the monitor when they come to you.

[MONITOR: Walk around to each participant and write down their crop decision on the Monitor Recording Form. Calculate how much water has been used by the group's crops. Announce how much water was used by the group.]

[FACILITATOR: subtract the water usage from the water level poster.]

[FACILITATOR: If the remaining amount of groundwater is less than 10 units, announce the end of the activity. Otherwise, move to the next round.]

\section{IF CONTINUE TO NEXT YEAR:}

This year has now ended.

\section{END ACTIVITY:}

[There is no longer sufficient groundwater available for the group.]

This was the last year and the activity is now ended. We are now going to gather your Decision Forms and we are going to discuss your experience in the exercise.

[MONITOR: Gather the participants' Decision Forms. Store the forms in the correct envelope.]

[FACILITATOR: Use the Discussion Guidelines to ask questions and encourage talking between the participants.]

[RECORDER: Use the Discussion Topics Instrument to check off the topics that are brought up by the participants. Also write down any issues or interesting points that are brought up by the group.] 


\section{ACTIVITY 2: YEARS WITH COMMUNICATION}

[FACILITATOR: If this is round 2 or later, add 5 units of water to the groundwater diagram.] This is the beginning of a new practice year. 5 units of groundwater have recharged.] There are units of groundwater available.

You have 45 seconds to talk with each other about the next year.

[MONITOR: time the group for 45 seconds. When that time has elapsed, raise your hand so the Facilitator can announce that there is no more talking.]

Your discussion time has ended.

Please make your decision on which crop you will plant for this round, Crop A or Crop B. Please carefully show your Decision Form to the monitor when they come to you.

[MONITOR: Walk around to each participant and write down their crop decision on the Monitor Recording Form. Calculate how much water has been used by the group's crops. Announce how much water was used by the group.]

[FACILITATOR: subtract the water usage from the water level poster.]

[FACILITATOR: If the remaining amount of groundwater is less than 10 units, announce the end of the activity. Otherwise, move to the next round.]

IF CONTINUE TO NEXT YEAR:

This year has now ended.

END ACTIVITY:

[There is no longer sufficient groundwater available for the group.]

This was the last year and the activity is now ended. We will gather your decision forms and hand you a short survey to be filled out. We will go over the survey with you. Thank you for providing this very valuable information.

[Only in the communities that are to be paid individual earnings, say:]

Once your questionnaire is filled out, we will give you your payment.

[MONITOR: Gather the participants' Decision Forms. Store the forms in the correct envelope.] When the survey is done, we will shortly begin a community-wide discussion meeting about this activity, and it would be wonderful if you could join us all to talk about your experience and ideas from the activity. We will not tell anyone about how each of you individually played, or what you (singular) decided, but we hope you will feel free to share your experiences and ideas on how this game might apply to groundwater management in this area.

Thank you so much for you time and attention! 


\section{Sampling}

The primary unit for site selection are habitation units (in contrast to the higher level political unit, the panchayat.) 1 or more habitations compose a panchayat. There are on average 4 panchayats within each watershed. FES has five watersheds in which it has field teams. However, only four watersheds have habitations that use bore wells, a necessary contextual feature for the project. The participants need to use groundwater in their agricultural practices, which necessitates bore wells.

In these 4 watersheds, there are 17 habitations available for running the field experiments or control. To expand the number of field sites for the study, we contacted Jana Jagriti, a partner NGO, to invite them to participate in the project. They have 3 watersheds available to bring the total number of villages to 30 project sites. We will end up with 29 project sites because we used one of the available FES sites as a pilot test.

With 29 sites, we will divide the sites into unequal thirds for the two treatments and the control group: 10-10-9 ("earnings"-“flat-fee to community"-“control").

Sampling strategy:

- NGO staff will go to the community in advance tell the Watershed Committee about plans to do the games (or the surveys in the control sites). The Watershed Committee will be asked to select 7 women and 7 men from different households that use groundwater (no couples from same household), with a request that they select households with a range of holding sizes. Explain that we want to have a discussion and activity related to groundwater use, and we would like to invite men and women from households that uses groundwater to come to the meeting at $X$ time. Those who participate would spend approximately $21 / 2$ hours, but it is a rather fun activity and [depending on the type of community] we will make a donation to the community fund to recognize their participation OR they will have a chance to make some money - between 200 and 500 rupees. Ask the committee to select 7 each men and women, but explain that on the day of the game, only 5 of each will be needed.

- From those who show up, separate them into men and women. Put 5 slips of paper numbered 1 through 5 into a bowl, along with blank slips, and let each person draw a slip. Those with a numbered slip would play.

- Before the rest leave, check that no couples were slected (man and woman from the same house). If they were, let them "draw straws" or something else to randomly select which one plays. The other goes home, and is replaced by another man or woman.

When invited, the participant needs to understand that approximately $21 / 2$ hours will be required to participate (from being seated, through the exercises, discussion, and survey, to the end of the community debriefing.) If the person declines to participate, the recruiters move on to the next person on the list. Continue until all 10 participants have been recruited. 


\section{Session Organization}

Each field site will consist of two groups of five participants each. One group will consist of men only and the second group will consist of women. The gender-segregated sessions will ensure each group is willing and able to speak freely about the exercise and its relevance to their lives.

The goal is to complete a site in a single visit. Group sessions are held sequentially. The Community Debriefing is scheduled for later in the day or evening, when the entire village will be available to meet.

Upon arriving at a village to begin the group sessions, a brief introduction is read to the village:

Thank you for allowing us to visit your community today. Before we get started, we want to briefly explain why we are here. As you are aware, groundwater depletion is major problem in this area and we are seeing increasing incidence of crop failures due to unavailability of water. Watershed activities being undertaken aim to address the availability of water from both demand and supply side. Today we are here for an activity which is part of a research project. This research is being undertaken in collaboration with International Food and Policy Research Institute and Arizona State University. We have requested the watershed committee to select 5 men and 5 women from your community to participate in a series of small activities. These activities are designed to allow us to learn a little about your community and your farming situation. This will be followed by a village Gram Sabha where the selected participants will share their experience and we will discuss on the probable options to address groundwater management.

Although we would love to have everyone join us in these activities today, we are only able to work with the ten people already invited. We need to begin our work, and we ask the first group of (Men/Women) to join us in the meeting area. We ask the other group to leave for a while and come back later when we can meet with you. Everyone else, you are welcome to watch us, but we request that you stay outside of the area, and please do not talk.

Thank you!

Each group session will require a minimum of three individuals to run:

1. Facilitator

2. Monitor

3. Recorder

The Facilitator reads the instructions and answers questions about the exercise. He or she also updates the Water Level indicator on the pin board when announcing the new water levels after the crop decisions. 
The Monitor records the crop decisions selected by the participants, and he writes their income on their Decision Forms. The Monitor also makes sure that the participants follow the rules (do not talk when not permitted, are not looking at each other's forms, etc.)

The Recorder writes down what participants talk about during discussion periods, using the Discussion Topic Instrument. They note who says what and notes any interesting discussions relevant to the history of the habitation. The Recorder also takes notes during the Community Debriefing.

When calculating the total number of trained staff required for the project, additional staff should be fully trained as redundant backups in case any of the primary staff become unavailable (due to sickness, family emergency, etc.)

In all sites, an FES hydrology team member will be the Facilitator. In the FES watersheds, the Recorder will be an FES field staff person, familiar with the habitation. In the Jana Jagriti watersheds, one of the JJ staff will fill the role of Recorder.

In the Individual Payment villages, following the end of the two games, earnings are calculated and a Payment Voucher is filled out and given to each Participant, indicating how much they will receive after they have filled out the Survey. In the Flat-Fee villages, the participant id number is given to the participant, to hold onto until they complete the survey.

The surveys are completed after the experiment sessions, during the break period before the Community Debriefing. Each field staff person sits with a participant and assists them with completing the survey. The Payment Voucher/Participant ID is used to ensure the survey is completed and marked with the correct Participant ID number. In the Individual Payment villages, after the survey is completed, the participant receives their cash payment.

\section{Treatments}

There are two treatments, plus a control group. In the two treatments, all sites will participate in the same set of activities: An initial exercise without any communication, followed by a discussion period facilitated but not dictated by the Facilitator, and concluded with a second exercise that includes a 45 -second discussion period between each round. Following the exercises, the participants will complete a survey and then be paid according to the assigned treatment.

In Treatment (A), the individual participants will be paid a fee according to their earnings in the two exercises. Each unit of income in the exercises will be worth 5 rupees. According to that figure, the minimum payment a participant can receive is 200 rupees (Choosing Crop A every round: 2 units $\times 20$ rounds $=40$ units $\times 5$ rupees $=200$ rupees), and the theoretical maximum that can be earned by an individual is 500 rupees (Choosing Crop B every round: 5 units $x 20$ rounds $=100$ units $\mathrm{x} 5$ rupees $=500$ rupees). Because every participant is guaranteed a minimum payment of 200 rupees, no show-up fee is needed.

In Treatment (B), the community will be paid a flat fee for participating in the study. 


\section{Documents \& Forms:}

In addition to the Checklist and this master Protocol document, additional forms need to be completed and translated into the needed site languages.

1. Consent Letter - All participants must read or have the Consent Letter read to them, so that we know they fully understand the meaning in the letter and so they can give their informed consent to participate in the project. THIS IS CRITICAL. IT CANNOT BE SKIPPED, OR GLOSSED OVER QUICKLY. Each participant must either sign a copy of the letter or their verbal consent must be recorded on the letter by a project staff person.

2. Signup/Payment Form - The name of each participant must be recorded into the signup sheet. At the end of the session, after each participant has completed their survey, they must sign that they have received the payment allotted for their project treatment.

3. Scripts - The session facilitators will need a concise script or bullet-point list of things to say every session. It is very important that the same things are said every time (and said the same way) and nothing is accidentally left out or added.

4. Participant ID Tags - Numbered slips 1-5 in plastic conference badges on lanyards, to make sure staff don't mix up participant positions. The participants wear the id around their necks for the session.

5. Monitor Forms - Two forms are needed for each group, one for each exercise (1 and 2). Ideally, the forms would be printed double-sided, so exercise 1 would be on one side, and exercise 2 on side two. Alternately, if double-sided printing is not possible, at time of printing each form pair should be stapled together. These forms need to be labeled correctly for the watershed, village, habitation, group, name of habitation (Location), and date and time, and game number (1 or 2). The watersheds, villages, and habitations need to be coded with numbers prior to the start of the project.

6. Decision Forms - The forms used by participants for recording their crop decisions each round and for the monitor to write their round earnings. Each participant will use two forms, one for each exercise.

7. Discussion Topic Journal - This is the form used by the Recorder to note what topics are discussed by the group during the discussion session. Who speaks and what they say should be noted.

8. Survey Instrument

9. Community Debriefing Protocol

10. Habitation Attributes Instrument - It may be very useful to use a standardized form for capturing the attributes of the habitation study sites currently recorded in FES' village records. The document included in the Dropbox folder is an example based off an attributes instrument from another study, which provides some example attributes that may be very useful (with tweaking.)

\section{Wrapping up Site Visit and Data Collection:}

The Facilitator is responsible for collecting and securely storing all experiment forms. Doublecheck that all the forms have been completed fully and correctly: Session details are completed: Date, time, Watershed, Village, Habitation Unit, and Group number. It is critical that all this 
information is filled out correctly on all the forms. Also make sure that the surveys are completed, and no questions are skipped (whenever possible.)

At the end of the day, the field staff should sit down and discuss the session. Record the team's observations in a journal: Did anything unusual happen? Did something go wrong or differently than usual? All of these details are useful, and when problems or surprises occur, it is very important to record that so they can be accounted for when analyzing the data. 


\section{A. Consent Letter: Individual Payments (Treatment A) \\ CONSENT FORM}

Watershed No.:

Village No.:

HU No.:

Group No.:

Participant No.:

Place and Date: Time of the activity: :AM/PM

You have been invited to participate in an activity that is part of a research project about the management of natural resources, especially groundwater irrigation. Due to your experience with groundwater irrigation, your participation is very important for this research. The exercises and discussions will provide important information for all of us, including your community. The funding for this project came from international organizations.

The duration of the activity is three hours. There are no foreseeable risks for your participation.

At the end of the activity, you will receive an amount of cash depending on your earnings during the activity.

You will be participating in the exercise twice. In each exercise, you will earn income for your cash payment. Between the two exercises, you will have an opportunity to talk about your experience and thoughts of the exercise.

After the activities are over, we will call you forward one by one to give you a voucher that shows you how much money you will receive. (date/time), we will meet with you and ask that you answer some questions on a short questionnaire about yourself, your household, and your community. Your thoughts and answers to these questions will be very helpful to us. What you earned in the activity and your answers on the questionnaire will be confidential. This information will be used for academic purposes only.

In addition to this activity you are invited to participate in a community discussion session to discuss the results of the activity. The discussion will be held in at $\mathrm{am} / \mathrm{pm}$.

Your participation in the activity is completely voluntary. You may leave the activity at any time, and you will receive what you earned up to that point. However, if you decide to leave before the activity is over, the activity also ends for the other group members.

The cash payment that you earn during the activity will be given to you after you finish answering the questions on the survey. All decisions in the activity are made in private and we will keep your decisions confidential. However, we cannot control participants' conversations about the activity after the activity is over.

If you want a copy of this consent form, please ask us for it. 


\section{B. Consent Letter: Flat-Fee (Treatment B) \\ CONSENT FORM}

Watershed No.:

Village No.:

HU No.:

Group No.:

Participant No.:

Place and Date: Time of the activity: AM/PM

You have been invited to participate in an activity that is part of a research project about the management of natural resources, especially groundwater irrigation. Due to your experience with groundwater irrigation, your participation is very important for this research. The exercises and discussions will provide important information for all of us, including your community. The funding for this project came from international organizations.

The duration of the activity is three hours. There are no foreseeable risks for your participation.

Your community will be paid $2000 \mathrm{Rp}$. today as a thank you for everyone's participation in today's activities.

You will be participating in the exercise twice. Between the two exercises, you will have an opportunity to talk about your experience and thoughts of the exercise.

(date/time), we will meet with you and ask that you answer some questions on a short questionnaire about yourself, your household, and your community. Your thoughts and answers to these questions will be very helpful to us. Your decisions in the activity and your answers in the questionnaire will be confidential. This information will be used for academic purposes only.

In addition to this activity you are invited to participate in a community discussion session to discuss the results of the activity. The discussion will be held in at $\mathrm{am} / \mathrm{pm}$.

Your participation in the activity is completely voluntary. You may leave the activity at any time.. However, if you decide to leave before the activity is over, the activity also ends for the other group members.

All decisions in the activity are made in private and we will keep your decisions confidential. However, we cannot control participants' conversations about the activity after the activity is over.

If you want a copy of this consent form, please ask us for it. 


\section{Monitor Form}

\begin{tabular}{|c|c|c|c|c|c|c|c|c|}
\hline \multicolumn{9}{|c|}{ Monitor Calculation Form } \\
\hline WS: & \multirow{2}{*}{$\begin{array}{l}\text { Village: } \\
\text { Time: }\end{array}$} & \multicolumn{2}{|c|}{ Habitation: } & \multicolumn{5}{|c|}{ Location: } \\
\hline Date: & & \multicolumn{2}{|c|}{ Group: 1} & \multicolumn{2}{|c|}{ Exercise: $\mathbf{1}$} & \multicolumn{3}{|c|}{ Men / Women } \\
\hline \multirow{2}{*}{ Round } & \multirow{2}{*}{ Water Available } & \multicolumn{5}{|c|}{ Player Crops } & \multirow{2}{*}{$\begin{array}{l}\text { Water } \\
\text { Used } \\
\end{array}$} & \multirow{2}{*}{$\begin{array}{c}\text { Water } \\
\text { Remaining } \\
\end{array}$} \\
\hline & & 1 & 2 & 3 & 4 & 5 & & \\
\hline Practice 1 & 50 & & & & & & & \\
\hline Practice 2 & $+5=$ & & & & & & & \\
\hline 1 & 50 & & & & & & & \\
\hline 2 & $+5=$ & & & & & & & \\
\hline 3 & $+5=$ & & & & & & & \\
\hline 4 & $+5=$ & & & & & & & \\
\hline 5 & $+5=$ & & & & & & & \\
\hline 6 & $+5=$ & & & & & & & \\
\hline 7 & $+5=$ & & & & & & & \\
\hline 8 & $+5=$ & & & & & & & \\
\hline 9 & $+5=$ & & & & & & & \\
\hline \multirow[t]{3}{*}{10} & $+5=$ & & & & & & & \\
\hline & TOTAL WATER UNITS: & & & & & & & \\
\hline & TOTAL EARNINGS: & & & & & & & \\
\hline
\end{tabular}


Participant Decision Form

\begin{tabular}{|c|c|c|c|}
\hline \multicolumn{4}{|c|}{ Decision Form } \\
\hline \multicolumn{4}{|l|}{ Participant: 1} \\
\hline WS: & \multicolumn{2}{|l|}{ Vill: } & HU: \\
\hline Group: $1 / 2$ & \multicolumn{2}{|c|}{ Game: 1} & \\
\hline & \multicolumn{2}{|c|}{ My Crop } & My Income \\
\hline Practice & A & B & \\
\hline \multirow[t]{14}{*}{ Practice } & A & $B$ & \\
\hline & $A$ & $B$ & \\
\hline & A & $B$ & \\
\hline & $A$ & $B$ & \\
\hline & $A$ & $B$ & \\
\hline & $A$ & $B$ & \\
\hline & $A$ & $B$ & \\
\hline & $A$ & $B$ & \\
\hline & $A$ & $B$ & \\
\hline & $A$ & $B$ & \\
\hline & $A$ & $B$ & \\
\hline & $A$ & $B$ & \\
\hline & $A$ & $B$ & \\
\hline & $A$ & $B$ & \\
\hline
\end{tabular}


Discussion Journal

Discussion Journal

\begin{tabular}{|ll|}
\hline Watershed: ___ Village: ___ Habitation: $\_$ & Group: \\
Date/Time: & Habitation Name:
\end{tabular}

\begin{tabular}{|l|l|}
\hline Speaker & \\
\hline & \\
\hline & \\
\hline & \\
\hline & \\
\hline & \\
\hline & \\
\hline & \\
\hline & \\
\hline & \\
\hline & \\
\hline & \\
\hline & \\
\hline & \\
\hline & \\
\hline & \\
\hline & \\
\hline & \\
\hline & \\
\hline & \\
\hline & \\
\hline & \\
\hline & \\
\hline & \\
\hline & \\
\hline & \\
\hline & \\
\hline & \\
\hline & \\
\hline & \\
\hline & \\
\hline & \\
\hline & \\
\hline & \\
\hline & \\
\hline & \\
\hline & \\
\hline & \\
\hline & \\
\hline & \\
\hline & \\
\hline & \\
\hline & \\
\hline & \\
\hline & \\
\hline & \\
\hline & \\
\hline & \\
\hline & \\
\hline & \\
\hline & \\
\hline & \\
\hline & \\
\hline
\end{tabular}

Page 1 of 4

Last Printed 3/12/13 2:11 PM Last Modified: 3/12/13 2:11 PM 


\section{Survey}

\section{INDIVIDUAL SURVEY}

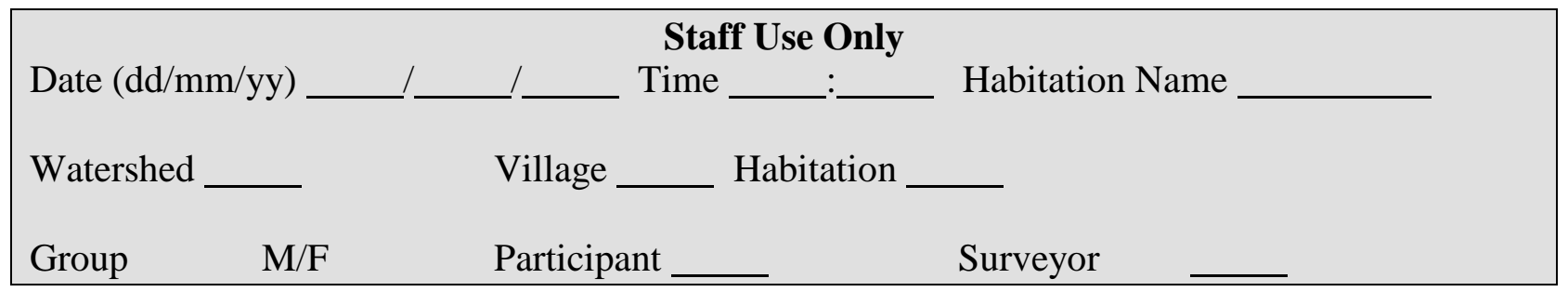

\section{SECTION I. RESPONDENT CHARACTERISTICS Please answer for yourself}

1. How old are you? years

2. Sex $\square$ Male $\square$ Female

3. Your Marital Status

$\square \quad$ 1. Married

2. Widowed
3. Divorced

4. Separated
5. Common law /Cohabiting

4. Your Caste

$$
\begin{aligned}
& \text { OC } \\
& \text { OBC } \\
& \text { SC } \\
& \text { ST }
\end{aligned}
$$

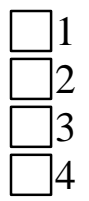

\section{Single}

5. What is the highest grade you have completed in school?

$\begin{array}{lr}\text { None } & \square 0 \\ \text { Adult literacy class } & \square 1 \\ \text { Primary school (1-5) } & \square 3 \\ \text { Secondary school (6-10) } & \square 4 \\ \text { Intermediate (11-12) } & \\ \text { Technical School } & \square 5 \\ \text { University } & \square 6\end{array}$

6. How long have you lived in this habitation?

YEARS

7. Who will work on your farm five years from now?

You

Other Relative

Hired Labor

Land Sold to Someone Else

\begin{tabular}{l}
$\square 1$ \\
$\square 2$ \\
\hline$\square 3$ \\
$\square 4$ \\
$\square 5$
\end{tabular}


8. Are you a member or leader of any community groups?

$\begin{array}{lcc}\text { Water Committee } & \text { Member } & \text { Leader } \\ \text { Water \& Sanitation } & \square 1 & \square 9 \\ \text { Committee } & \square 2 & \square 10 \\ \text { Panchayat } & \square 3 & \square 11 \\ \text { Self-Help } & \square 4 & \square 12 \\ \text { Forest Protection (VSS) } & \square 5 & \square 13 \\ \text { Farmer's Club } & \square 6 & \square 14 \\ \text { Mother's Committee } & \square 7 & \square 15 \\ \text { Other: } & \square 8 & \square 16\end{array}$

\section{SECTION II. HOUSEHOLD CHARACTERISTICS Please answer for your entire household}

9. Number of people (adults and children) who lived in house during last year for at least six months

Adult

Children (under age 16)

10. How long has your family (ancestors) lived in this habitation?

(For married women, answer for your husband's family)

$$
\begin{aligned}
& <4 \text { Years } \\
& 5-10 \text { Years } \\
& 11-20 \text { Years } \\
& 21-50 \text { Years } \\
& >50 \text { Years }
\end{aligned}
$$

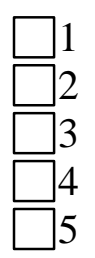

11. What are the sources of livelihoods for your household and which are the three most important (please rank in order 1,2,3)?

$\begin{array}{lrl}\text { Irrigated Farming } & \square 1 & \\ \text { Rain-Fed Farming } & \square 2 & \\ \text { Animal Husbandry } & \square 3 & \\ \text { Farm Wage Labor } & \square 4 & \\ \text { Off-Farm Wage Labor } & \square 5 & \\ \text { Business } & \square 6 & \\ \text { Salaried Employment } & \square 7 & \\ \text { Remittances, Pensions } & \square 8 & \\ \text { Other } & \square 9 & \end{array}$

If Other, please write that livelihood: 
12. Do you own or rent:

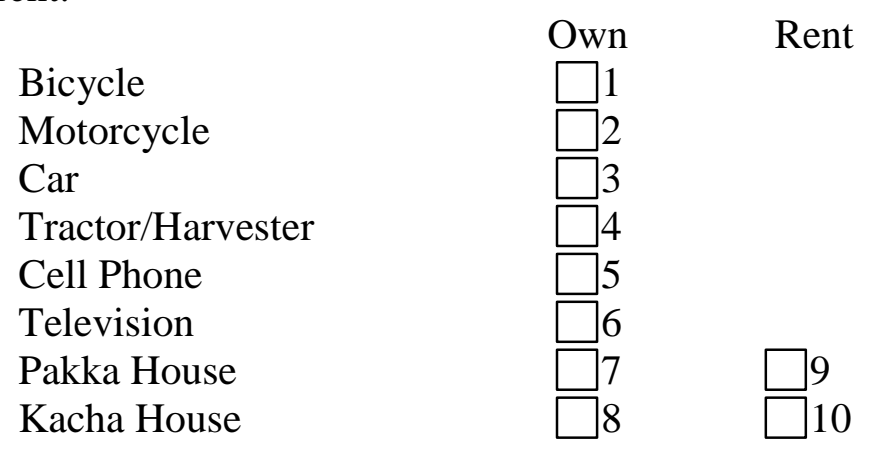

13. If you have a cell-phone, how many people in your habitation have you put into your cell phone address book?

No One

Very Few

About Half

More Than Half

Almost Everyone

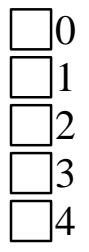

\section{SECTION III. COLLECTIVE ACTION}

14. Please tell me whether in general you agree or disagree with the following statements:

Please check the most appropriate response A, B, C or D.

A $=$ Agree Strongly

$\mathrm{B}=$ Agree Somewhat

$\mathrm{C}=$ Disagree Somewhat

$\mathrm{D}=$ Disagree Strongly

A $\quad$ B $\quad$ C $\quad$ D

1. Most people in this community are basically honest and can be trusted.

2. People are always interested only in their own welfare.

3. In this community, one has to be alert or someone is likely to take advantage of you.

4. I do not pay attention to the opinions of others in the community.

5. Most people in this community are willing to help if you need it.

6. I feel accepted as a member of this community. 
7. If a mother in this village has an emergency and needs to leave her baby for the day, she will easily find someone in this village she can trust with her baby

8. If someone loses a pig, goat or chicken he or she will easily find others in this village to help to seek and find it.

9. If a neighbor in this village lends some money to another neighbor, it is very likely that the lender gets her money back

15. Think about the people that live in this village. If you had a newly born baby, in how many houses would you be able to leave your baby and trust them in case you had to leave for the day because of an emergency?
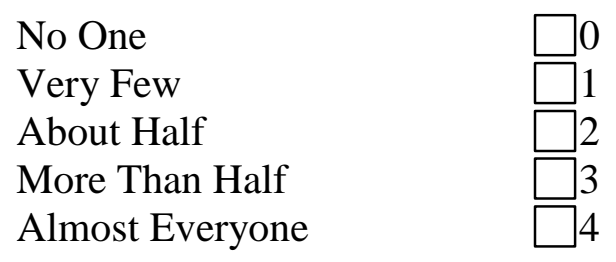

16. If you had to borrow a small amount of money for an emergency, from how many of your neighbors would you be able to get the money with no interest?

No One

Very Few

About Half

More Than Half

Almost Everyone

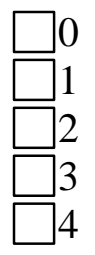

17. How much influence do you think you and people like you can have in making this village a better place to live?
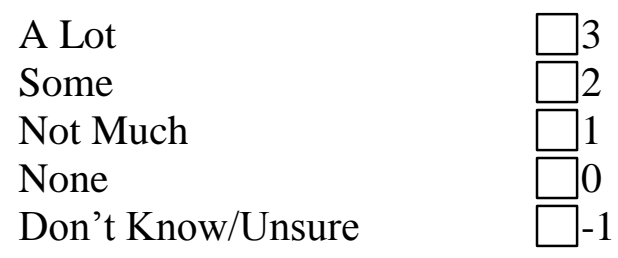

18. Suppose that 10 of your neighbors are invited to help in community activities. How many would show up?

Neighbors 


\section{Section IV. Land \& Water use}

19. Last year, how much land did your household have and how was it watered:

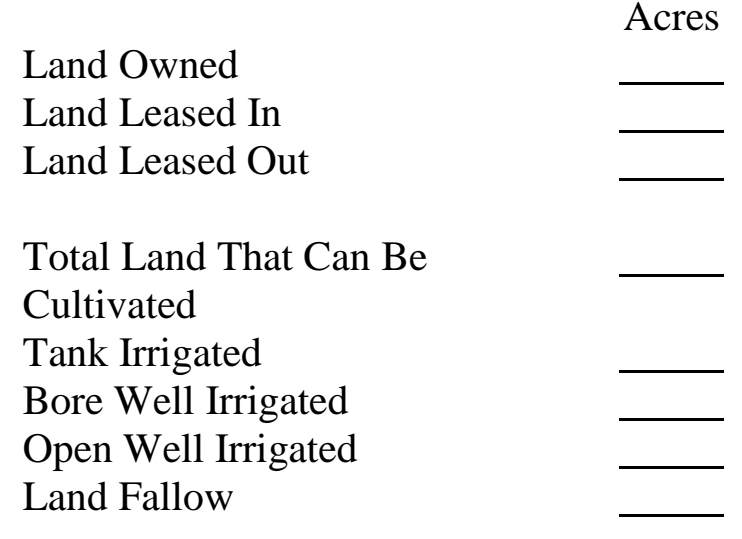

20. Who owns the bore well that you use to irrigate your crops? (Check One)

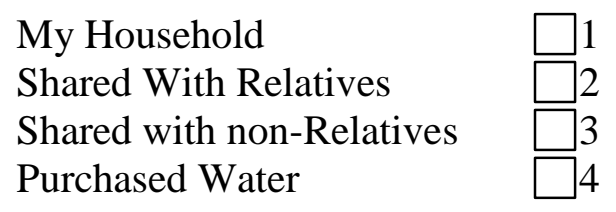

21. If you use water from an open well to irrigate your crops, who owns the open well? (Check One)

$\begin{array}{lr}\text { My Household } & \square 1 \\ \text { Shared With Relatives } & \square 2 \\ \text { Shared with non-Relatives } & \square 3 \\ \text { Purchased Water } & \square 4\end{array}$

22. What kind of crops did you grow last year?

\begin{tabular}{|c|c|c|c|c|c|}
\hline Crops Grown & $\begin{array}{c}\text { Total Area } \\
\text { (acres) }\end{array}$ & $\begin{array}{c}\text { Total } \\
\text { Production } \\
\text { (quintal) }\end{array}$ & Surface & $\begin{array}{l}\text { rigation } \\
\text { Ground } \\
\text { Water }\end{array}$ & $\begin{array}{l}\text { Rain } \\
\text { Only }\end{array}$ \\
\hline \multicolumn{6}{|c|}{ Kharif Season } \\
\hline \multicolumn{6}{|c|}{ Rabi Season } \\
\hline
\end{tabular}




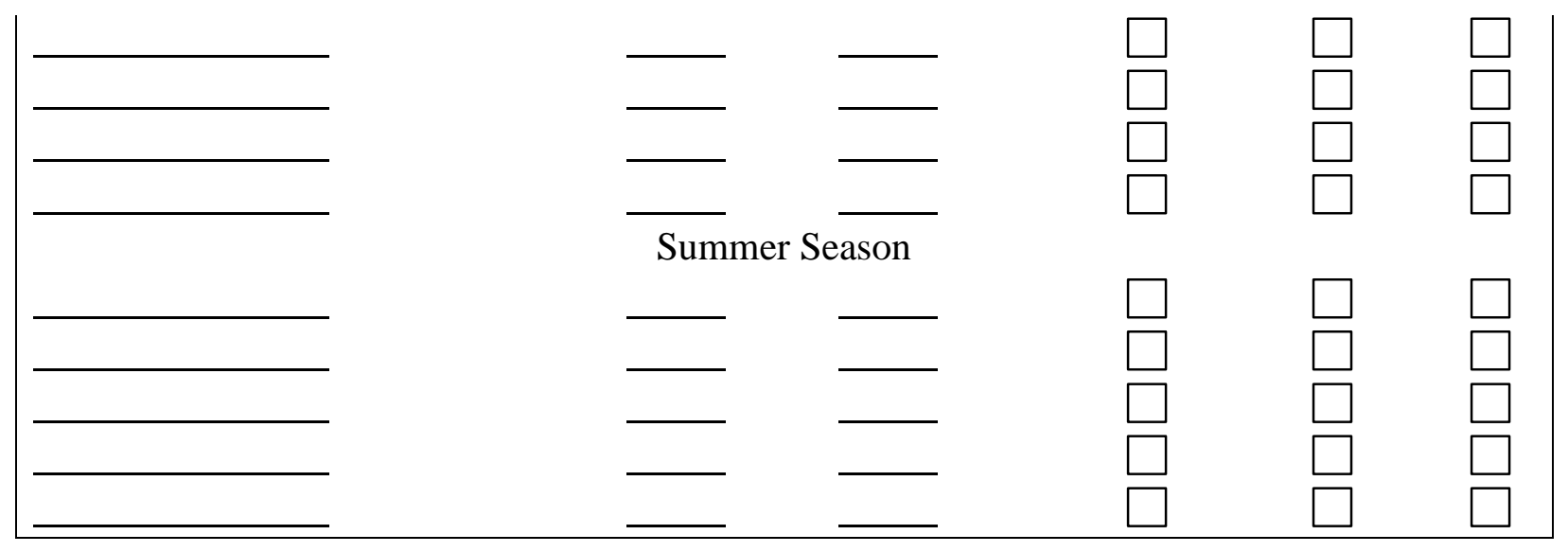

23. How much did you pay last year?

Water Purchased

System Maintenance

24. Over the last ten years, do you think the water table

$\begin{array}{ll}\text { Has Fallen } & \square-1 \\ \text { Is Unchanged } & \square 0 \\ \text { Has Risen } & \square 1\end{array}$

25. What do you think should be done to improve the water table?

26. Do you have some final remarks on the groundwater exercise? You can write them here: 


\section{Community Debriefing Protocol}

The debriefing session will be held immediately following the conclusion of the Experiment sessions. By holding two simultaneous sessions, Men and Women groups, followed by the Community Debriefing, hopefully it will be possible to include all or most of the experiment participants in the debriefing with the experience and lessons fresh on everyone's minds. If it is necessary to schedule the Debriefing at a different time, it should be set for a time recent enough to the experiment for the participants to have fresh memory of the experience. The Debriefing is open to the entire community; ensure during the scheduling and setup for the field visit that the local contacts in the community advertise clearly that everyone from the community is welcome to join this session.

Open the session, explaining that the staff will not reveal the actions taken by any individuals in the games, but during the debriefing, the participants are free to share or keep private their own actions in the game, they are free to share what they are comfortable sharing.

There are several main points each debriefing session should cover in all communities, but beyond these general points, allow the community to drive the discussion. Allow the session to go where it needs to for the community.

1. Tell everyone: This is a fun activity to create dialog between them, academics and policy makers about a subject that they all care about. We use games because we want to understand how people make decisions. [With villages where we give cash payments: We use money because we want to study the decision-making process with real consequence for their pockets, just like in reality.]

2. Give a brief presentation about the game. Most debriefing participants won't be familiar with the game, so explain the game, similar to how the game was presented during the experiment. (We should be able to reuse the posters used for the games: Water/Payoff for Crop A vs. B; Results planting AAAAA vs. BBBBB).

2. Show the decisions that will lead to the most earnings (AAAAA) and the effect on available water, and the decisions that will lead to the least earnings (BBBBB) and its effect on water level. DON'T: use any language that implies one is worse or wrong. We DO NOT judge one option against the other; just describe the effects neutrally. (Reuse the poster that shows the difference between Planting AAAAA vs BBBBB.)

3. Show the results of the games, describe the general averages (NO SPECIFIC ABOUT INDIVIDUAL PARTICIPANTS). If a whiteboard is available, the general averages could be drawn as lines or bars on a picture. Alternatively, it may be easier to print a large poster to point at the different levels. Show the amount of Crop A and Crop B planted, on average, by each group. State how much each group earned.

4. Begin open discussion with community. Ask them questions to jump-start the discussion, but let the community members to talk freely, particularly the game participants: 
- What happened during the first game (first 10 rounds)? What do you think was happening? What were you thinking?

- What did you talk about during the discussion between games?

- What happened during the second game?

- Was there a difference; why do you think that happened? Were you surprised by anything that happened? Why or why not?

- Was there a difference between the groups? If so, why was there a difference?

- "What did you think about when making your decisions?"

- Does this game relate to your situation? What are differences that you think are important?

- Are there different kinds of crops that you have to choose between that require different amounts of water? How do you decide which to grow? What is important to you when you decide what crops to plant?

- Are groundwater levels falling, rising, or steady in this community? (refer to the groundwater records of the watershed committee, if available)

- Do you think that groundwater levels are a problem? Do you think it will be a problem in the future?

- Does what you do affect water available for others (or does what others are doing affect the water you have available?)

- Does the game give you any ideas about your situation? Do you have any suggestions?

\section{DOS \& DONTS}

- DO: Get the community's trust that you will not show anyone the individual data, their decisions. The Facilitator is responsible for collecting all the experiment forms and storing them securely in a backpack. Make a fuss in the community discussion that all the forms are safe in your backpack and no one can look at it.

- DO: Allow participants to discuss and share their thoughts and opinions. The debriefing must be a comfortable environment for the community--those who participated in the games AND those who did not--to talk freely about the games.

- DO: Balance the community discussion between the "loud and extroverted" talkers and the shy, quiet members. Make sure no one is monopolizing the truth.

- DONT: Reveal how any individual acted in the game. Do not show any individual results.

- DONT: Tell the community that we are expecting/hoping to see them change their wateruse because of the game. We are watching and learning from them.

- DONT: Tell the community that we are continuing to measure their water in order to test the effects of the games.

- DONT: Tell them what they SHOULD DO or MUST DO. DONT tell them how they should play the game to make more money or save water. They must come up with their own ideas and suggestions, if they feel like it. We record what they say and the ideas that they come up with. 


\section{Appendix 2. Supplemental Statistics}

Table A2.1 Study Locations Summary Statistics

\begin{tabular}{ccccccccc}
\hline Treatment & $\begin{array}{c}\text { Watershed } \\
\text { Number }\end{array}$ & $\begin{array}{c}\text { Panchayat } \\
\text { Number }\end{array}$ & $\begin{array}{c}\text { Vill. } \\
\text { No. }\end{array}$ & $\begin{array}{c}\text { No. of } \\
\text { Houses }\end{array}$ & $\begin{array}{c}\text { Agri- } \\
\text { land } \\
\text { (Acres) }\end{array}$ & $\begin{array}{c}\text { No. } \\
\text { of } \\
\text { Bore } \\
\text { wells }\end{array}$ & NGO & $\begin{array}{c}\text { Years in } \\
\text { Program }\end{array}$ \\
\hline A & 1 & 1 & 1 & 193 & 1250 & 15 & FES & 6 \\
A & 1 & 1 & 2 & 14 & 95 & 4 & FES & 6 \\
C & 1 & 1 & 3 & 30 & 220 & 6 & FES & 6 \\
B & 1 & 1 & 4 & 33 & 165 & 1 & FES & 6 \\
A & 2 & 1 & 5 & 33 & 100 & 2 & FES & 6 \\
B & 2 & 1 & 6 & 31 & 48 & 0 & FES & 6 \\
B & 2 & 1 & 7 & 100 & 210 & 9 & FES & 6 \\
C & 2 & 1 & 8 & 64 & 110 & 10 & FES & 6 \\
C & 2 & 1 & 9 & 28 & 250 & 4 & FES & 6 \\
A & 2 & 1 & 10 & 19 & 250 & 5 & FES & 6 \\
C & 3 & 1 & 11 & 66 & 640 & 6 & FES & 6 \\
B & 3 & 1 & 12 & 107 & 896 & 67 & FES & 6 \\
B & 4 & 2 & 13 & 114 & 560 & 9 & FES & 6 \\
A & 4 & 2 & 14 & 30 & 125 & 4 & FES & 6 \\
C & 4 & 2 & 15 & 52 & 25 & 0 & FES & 6 \\
A & 4 & 2 & 16 & 250 & 550 & 16 & FES & 6 \\
C & 5 & 3 & 17 & 68 & 70 & 13 & JJ & 20 \\
B & 5 & 3 & 18 & 95 & 80 & 10 & JJ & 20 \\
A & 5 & 3 & 19 & 27 & 120 & 19 & JJ & 20 \\
B & 5 & 3 & 20 & 22 & 70 & 14 & JJ & 20 \\
C & 6 & 4 & 21 & 82 & 125 & 14 & JJ & 19 \\
B & 6 & 4 & 22 & 54 & 30 & 6 & JJ & 19 \\
C & 6 & 4 & 23 & 54 & 24 & 4 & JJ & 20 \\
A & 6 & 4 & 24 & 43 & 32 & 9 & JJ & 19 \\
A & 6 & 4 & 25 & 65 & 22 & 5 & JJ & 20 \\
C & 7 & 4 & 26 & 92 & 130 & 11 & JJ & 19 \\
A & 7 & 4 & 27 & 61 & 92 & 11 & JJ & 20 \\
B & 7 & 4 & 28 & 94 & 140 & 14 & JJ & 19 \\
\hline
\end{tabular}

Treatments: A = Individual Payments, $\mathrm{B}=$ Flat Fee, $\mathrm{C}=$ Control 
Table A2.2 Summary Statistics

\begin{tabular}{lccccc}
\hline \multicolumn{1}{c}{ Variable } & Observations $^{1}$ & Mean & Std. Dev. & Min & Max \\
\hline Water use & 3100 & 1.664 & 0.950 & 0 & 3 \\
Years in program & 3400 & 11.588 & 6.688 & 6 & 20 \\
Communication & 3400 & 1.502 & 0.500 & 1 & 2 \\
Available water & 3100 & 33.287 & 9.960 & 16 & 50 \\
Female & 3400 & 0.498 & 0.500 & 0 & 1 \\
Age & 3380 & 38.500 & 12.872 & 20 & 86 \\
Caste & 3380 & 3.224 & 0.870 & 1 & 4 \\
Education & 3380 & 2.024 & 1.511 & 0 & 6 \\
Household size & 3360 & 4.805 & 2.126 & 2 & 12 \\
Area owned & 3380 & 2.105 & 1.396 & 0 & 10 \\
Area tank- irrigated & 3240 & 0.131 & 0.267 & 0 & 1.6 \\
Area groundwater irrigated & 3400 & 0.630 & 0.618 & 0 & 4 \\
& & & & & \\
\hline Obs & & & & & \\
\hline
\end{tabular}

${ }^{1}$ Observations refer to number of participants times number of decisions. 
Table A2.3 Caste Distribution of Sample

\begin{tabular}{l|r} 
Caste & Percent \\
\hline ST & 6.51 \\
SC & 9.47 \\
OBC & 39.05 \\
OC & 44.97 \\
\hline Total & 100.00
\end{tabular}

Table A2.4 Number of rounds played in the games.

\begin{tabular}{l|rrr}
$\begin{array}{l}\text { Game } \\
\text { Length }\end{array}$ & $\begin{array}{c}\text { Number of } \\
\text { Games. }\end{array}$ & Percent & Cumulative \\
\hline 4 & 1 & 1.47 & 1.47 \\
5 & 2 & 2.94 & 4.41 \\
6 & 1 & 1.47 & 5.88 \\
7 & 6 & 8.82 & 14.71 \\
8 & 8 & 11.76 & 26.47 \\
9 & 6 & 8.82 & 35.29 \\
10 & 44 & 64.71 & 100.00 \\
\hline Total & 68 & 100.00 &
\end{tabular}

